\title{
Gender gaps in Spain: policies and outcomes over the last three decades
}

\author{
Nezih Guner • Ezgi Kaya • Virginia Sánchez-Marcos
}

Received: 22 August 2012 / Accepted: 7 February 2014 / Published online: 14 March 2014 (C) The Author(s) 2014. This article is published with open access at SpringerLink.com

\begin{abstract}
We document recent trends in gender equality in employment and wages in Spain. Despite an impressive decline in the gender gap in employment, females are still less likely to work than males: about $76 \%$ of working age males and $63 \%$ of working age females were employed in 2010. If females work they are more likely to be employed part time and with temporary contracts. The large increase in female employment, from $28 \%$ in 1977 to $63 \%$ in 2010, was accompanied by a significant decline in fertility. The gender gap in wages, after controlling for worker and job characteristics as well as for selection, is high. It was about $20 \%$ in 2010 , quite close to its value in 1994. Furthermore, the gender gap in wages is driven mainly by differences in returns to individual characteristics. While women are more qualified than men in observable labor market characteristics, they end up earning less. There have been several important policy changes that try to help families reconcile family
\end{abstract}

\footnotetext{
This paper is an updated version of a report, with the same title, that was written as a background paper for the World Development Report 2012: Gender Equality and Development by the World Bank. We thank Victor Aguirregabiria (editor) and two anonymous referees for very helpful comments. We also thank Effrosyni(Efi) Adamopoulou, Matt Devanthal, Libertad Gonzalez and Manuel Bagues for their comments. The authors thank RecerCaixa for support. Kaya acknowledges financial support from the Spanish Ministry of Science and Innovation through grant "Consolidated Group-C" ECO2008-04756 and FEDER. Sánchez-Marcos also thanks Spanish MCYT for Grant ECO2009-09614.
}

\section{N. Guner $(\bowtie)$}

ICREA-MOVE, Universitat Autònoma de Barcelona and Barcelona GSE, Barcelona, Spain e-mail: nezih.guner@movebarcelona.eu

\section{E. Kaya}

Universitat Autònoma de Barcelona, Barcelona, Spain

e-mail:kayaez@gmail.com

V. Sánchez-Marcos

Universidad de Cantabria, Santander, Spain

e-mail: virginia.sanchez@unican.es 
responsibilities with market work. The existing literature suggests that households do react to incentives generated by different policies and policy changes are at least partly responsible for changes in female labor supply. In recent decades, the large inflow of immigrants, who provided relatively cheap household services, allowed more educated women to enter the labor market. Policy challenges, however, remain.

Keywords Gender employment gap · Gender wage gap · Occupational segregation · Quantile regressions · Selection · Public policy

JEL Classification $\mathrm{J} 16 \cdot \mathrm{J} 21 \cdot \mathrm{J} 22 \cdot \mathrm{J} 24$

\section{Introduction}

The Spanish labor market experienced a remarkable transformation over the last three decades as the female employment rate increased from 25 to $63 \%$ between 1977 and 2013. Indeed, the decline of the gender employment gap in Spain has been among the highest in OECD countries (OECD 2008). Nevertheless, the gender gap in employment, which was close to $19 \%$ in 2008 , is still one of the highest among OECD countries, and is surpassed only by two other European Union countries in OECD, Italy and Greece (OECD 2008). Furthermore, the unemployment rate has been substantially higher among females than males (10 vs. $5 \%$ between 2005 and 2008). The gender gap in wages also remains high; it was about $20 \%$ in 2010.

Furthermore, Spain lags behind other OECD countries in coverage and generosity of family policies. The parental leave system is quite restrictive, providing about 16 weeks of maternity and parental paid leave. This is about half of the OECD average and significantly lower than in countries like France (45.5 weeks), Germany (48.8 weeks), or Sweden (46.6 weeks). ${ }^{1}$ Child care remains a significant barrier to the employment of mothers and public subsidies are limited. The childcare fees for a two-year-old in 2004 were about $30 \%$ of average wages, a figure surpassed only by Luxembourg and Switzerland among OECD countries (OECD 2007). Spain spends about $1.5 \%$ of its GDP on family benefits (transfers to families and children), while the average for OECD is about $2.3 \% .^{2}$

The current study has two parts. In Sect. 2 we describe changes in public policy that were introduced to make family and work more compatible. We also summarize both empirical and quantitative papers in the literature that analyze the role of different public policies on female labor market outcomes. In Sect. 3 we document the trends in employment and gender wage gaps for recent decades and highlight some key findings. First, we discuss the role of compositional changes in accounting for the reduction in the gender employment gap. We show that there are important non-compositional changes that are left to be possibly accounted for changes in public policies and institutions. For our analysis of employment, we use the Encuesta de Población Activa

\footnotetext{
${ }^{1}$ Source: OECD (2014), OECD Family Database, OECD, Paris (http://www.oecd.org/social/family/ database).

2 Source: OECD (2014), OECD Social Expenditure Database (SOCX), OECD, Paris(www.oecd.org/social/ expenditure.htm).
} 
(EPA) data, from 1977 to 2013. Second, using the same data set, we document the substantial gender segregation in occupations which exists in the Spanish labor market. Finally, we use the first wave of the European Community Household Panel (ECHP) for 1994, and the cross-sectional component of the European Union Statistics on Income and Living Conditions (EU-SILC) for 2004 and 2010 to document the gender wage gap and to explore its determinants. We show that the gender gap in wages is driven mainly by differences in returns to individual characteristics and that there is positive self-selection of women into the labor market (so that more productive women are the ones who choose to work). We also find that both sticky-floor and glass-ceiling effects on female wages are present. We conclude in Sect. 4.

\section{Institutions and policies}

Spain went through dramatic institutional changes over the period of analysis. Table 1 provides a chronology of major policy changes. The return to democracy in 1977 and the entry into the EU in 1986 were accompanied with reforms that changed labor markets in fundamental ways and affected the evolution of the gender gaps. In this section we describe these reforms and, based on findings from the existing literature, discuss their potential effects.

\subsection{Family-friendly policies}

Child Care Arrangements: The cost and availability of child care is possibly one of the most important factors determining female labor supply decisions. Between 2005 and 2013 the "care of children or sick adults" together with "other family responsibilities" are the main reasons for women to stay out of the labor market (chosen by $35.0 \%$ of respondents), while they do not seem to affect the labor force participation of males (chosen only by $1.8 \%$ of respondents). ${ }^{3}$ Crespo and Mira (2013) also document a negative relation between poor health of parents and employment of their daughters in Southern European countries (Greece, Italy and Spain), where formal care arrangements are limited.

An important source of child care is provided by the public education system. School enrollment rates at early ages have been increasing during last two decades, mainly due to a major reform of education in 1990 (Ley 1/1990, de 3 de octubre, named LOGSE) that introduced the possibility for children younger than three to be enrolled in the public school system. The reform had the largest effect on children who are three years old as the law requires schools to admit these children whenever their parents request admission. Indeed, children under three years old are rarely enrolled in the public education system since public education at this level is not widely available. As we report in Table 2, the enrollment rate was only $6 \%$ for children younger than one and $35 \%$ for two-year-old children in 2007. In contrast, at the age of three, $97 \%$ of children were enrolled, which is significantly higher than it was in $1986(17 \%)$ and

\footnotetext{
3 Source: Encuesta de Población Activa (EPA). See Sect. 3.1 for further details on EPA data set.
} 
Table 1 Policies

\begin{tabular}{ll}
\hline 1978 & Legalization of Contraceptives (Real Decreto 2275/78, de 7 de octubre) \\
1981 & DivorceLaw (Ley 30/1981,de 7 de julio) \\
1985 & Abortion is allowed under certain circumstances (Ley Orgánica 9/85, de 5 de julio) \\
1989 & Extension of paid maternity leave from 14 to 16 weeks (Ley 3/1989, de 3 de marzo) \\
1990 & LOGSE: extension of enrollment in public schools to ages 0-3 (Ley 1/1990, de 3 de octubre) \\
1991 & Separate taxation of couples (Ley 18/91, de 6 de junio) \\
1999 & Family friendly package: right to part-time for parents of 0-6 \& unpaid leave \\
1999 & Fo up to 3 years for parents (Ley 39/1999, de 5 de noviembre) \\
2003 & $\begin{array}{l}\text { Cash benefits to working mothers 0-3 and increase in tax deduction for } \\
\text { children (Ley 46/2002, de 18 de diciembre) }\end{array}$ \\
2005 & Unilateral divorce (Ley 15/2005, de 8 de julio) \\
2007 & Universal childbenefit (Ley 35/2007, de 15 de noviembre) \\
2010 & Abortion during first 14 weeks of pregnancy (Ley Orgánica 2/2010, de 3 de marzo) \\
\hline
\end{tabular}

Table 2 Enrollment rates by child age

\begin{tabular}{llclccc}
\hline & $<1$ year & 1 year & 2years & 3 years & 4 years & 5 years \\
\hline $1986-1987$ & & & 17 & 86 & 100 \\
$1991-1992$ & & & 39 & 97 & 100 \\
$1996-1997$ & 1 & 5 & 12 & 67 & 99 & 100 \\
$2001-2002$ & 2 & 9 & 93 & 100 & 100 \\
$2007-2008$ & 6 & 20 & 35 & 97 & 98 & 99 \\
\hline
\end{tabular}

Source INECSE (http://www.mecd.gob.es/inee/publicaciones/indicadores-educativos/Sistema-Estatal. html) and Instituto Nacional de Estadística

also above the EU-27 average (75\%). ${ }^{4}$ Nollenberger and Rodriguez-Planas (2011) study this legislation and show that it led to an $8 \%$ increase in the employment of mothers whose youngest child is three years old. Furthermore, the effect seems to persist as women who benefited from this policy continue to work more even when their child is older than three.

In addition to the public school system, privately provided child care services (nurseries or kindergartens) play a crucial role for children younger than 3 years old. According to the Ministry of Education, in 2006 the number of children between 0 and 2 years old in private schools was $32 \%$, larger than the number of children in public schools. ${ }^{5}$ The monthly average price of full-time attendance of private nurseries was about 256 euros in 2005 , with substantial variation across regions. ${ }^{6}$

Child care cost may be a key determinant of female labor supply. Attanasio et al. (2008) found that one of the main driving forces of the increase in married women's

\footnotetext{
4 See Instituto Nacional de Estadística.

5 Ministerio de Educación. Estadística de Enseñanza no Universitaria 2006-2007.

6 Murcia is the cheapest region with 198 euros per month while Álava the more expensive with 305 euros. See Consumer (2005).
} 
labor supply in the United States (when one compares cohorts of women born in the 1940s and 1950s) was a decrease in child care costs. Encouraging female labor supply at early ages is important since this may have an impact on their attachment to the labor market later in life. As a result, it is reasonable to expect that higher female employment rates at early ages for the youngest cohorts of women in Spain would generate a sustained increase in female labor supply in the coming years. ${ }^{7}$ Baizán (2009) shows that child care availability also has a positive effect on fertility in Spain.

Formal childcare services may be substituted or complemented by informal childcare provided by family networks. Tobío (2003), based on a survey conducted in 1998, studies alternative forms of childcare used by parents. She finds that grandparents are a key part of how parents reconcile family and work. Higher life expectancy together with low geographical mobility in Spain allows grandparents to have a high level of involvement with their grandchildren. ${ }^{8}$ According to this survey, among mothers who participate in the labor market, $77 \%$ live in the same town with other relatives, and $56 \%$ of working mothers live in the same town as their mothers. Among those who live in the same town, $50 \%$ live in the same neighborhood. About half $(51 \%)$ of grandmothers who live in the same neighborhood as their grandchildren are involved with grandchildren's care while this figure stands at $38 \%$ for those who live in the same town.

A final and important aspect of child care arrangements in Spain is the role of immigration. The number of immigrants has increased dramatically over the last decade in Spain and the number of immigrants increased from 637,085 (1.6\% of population) in 1998 to $5,648,671$ ( $12 \%$ of population) in 2009. A substantial fraction of immigrant women is employed in household services, including both housekeeping and caring for children and elderly dependents (in many cases as part of the underground economy). Farré et al. (2011) investigate the effects of immigrants on female labor supply of highly skilled (college-educated) native women. They find that immigration allowed women to take shorter children-related breaks from the labor market and enabled later retirement from the labor force.

Parental Leave Policies: There are three types of policies providing special treatment for parents at work. First, parents can take 16 weeks of paid leave (Ley 3/1989, de 3 de marzo), of which 6 weeks have to be enjoyed by the mother. Available empirical evidence (see for instance Waldfogel et al. (1999), Waldfogel (1998), Ruhm (1998)) suggests that parental leave policies have a positive effect on employment of females of childbearing age as well as wages since they increase the likelihood that a woman will return to her employer after childbirth. Within the context of a labor matching general equilibrium model (Erosa et al. 2010) find that parental leave policies may have important effects on fertility and labor market decisions. Finally, Sánchez-Marcos (2013) explores the quantitative effects a one-year paid maternal leave policy in a life-

\footnotetext{
7 Bick (2012) studies potential effects of recent reforms in Germany that increase the availability of subsidized child care for mothers and show that they have substantial effects on labor supply of females with children. Guner et al. (2013) study effects of providing more generous child care subsidies in the US and show that they can increase married female labor supply significantly.

8 García-Morán and Koehn (2012), using German data, show that women who live close to their parents or parents-in-law are more likely to have children and more likely to work. They face, however, lower wages as the child care provided by the grandparents restricts women's geographic job mobility.
} 
cycle model of labor supply and savings, and finds that there are substantial effects on the employment rate of mothers of young children, although employment rates later in life are not affected. While job protection associated with maternal leave also has a positive effect on wages, this effect is dominated by selection as the increase in female labor supply results in lower productivity women entering the labor force.

In addition to paid parental leave, mothers can enjoy $1 \mathrm{~h}$ of leave per day for breastfeeding (up to nine months after birth). Mothers are allowed, in general, to accumulate these hours to extend the paid parental leave.

Second, a new law was passed in 1999 (Ley 39/1999, de 5 de noviembre, named Law to Promote the Conciliation of Work and Family Life) that specifically aimed at helping to balance family and work. This new law introduced the possibility of family-friendly arrangements between the worker and the firm. In particular, the law allows parents to ask for an unpaid leave of up to three years after a birth. However, the same job position is only guaranteed if the spell is shorter than one year. After that period only a job of similar category is guaranteed. These unpaid leaves are taken into account for the seniority calculation and thus they do not affect negatively automatic wage increases or severance payments. Furthermore, the recent Law on Equal Opportunities between Women and Men (Ley 3/2007, de 22 de marzo) increased the duration of unpaid parental leave that is counted for retirement social security benefits from 1 to 2 years. Lapuerta et al. (2010) explore the incidence of unpaid parental leave among workers. They show that only about $46 \%$ of women with children under 3 years were entitled to parental leave in 2006 since most Spanish women leave the labor market during the first few years of maternity. Furthermore, even among those who qualify, the use of parental leave is very limited, comprising only $3 \%$ of entitled mothers in December 2006. Among parents who use the benefits, women are much more likely to be on parental leave than men (only five of every 100 parents using benefits are men). Among women, those with full-time permanent contracts and high level of education are more likely to enjoy unpaid parental leave. However, unpaid parental leaves are shorter among high educated women than among low educated ones.

Flexibility at Work for Parents: The Law to Promote the Conciliation of Work and Family Life also allows parents of children under the age of 7 to reduce their daily hours worked. In particular, the law makes it illegal to fire a worker if she/he asked for a reduction in hours in the past. In practice, the law mainly protects workers with permanent contracts since the employer is not forced to renew a fixed-term contract. Fernández-Kranz and Rodríguez-Planas (2013) found that this law indeed encouraged the primary caregiver (usually mothers) to remain employed in part-time work. They also find, however, that the law had adverse effect on female employment, as firms became less likely to hire childbearing-aged women and to promote them into good jobs, and more likely to let them go relative to their male counterparts.

In response to the low incidence of part-time work during the nineties, a law aimed at promoting flexibility of hours worked was passed in 1998 (Ley 15/1998, de 27 de noviembre). The new law focused on removing discrimination against part-time workers as compared to full-time workers in terms of social welfare protection and favoring job stability of part-time contracts. In spite of this, Blázquez and Ramos (2009) find that part-time employment in Spain is mainly related to the difficulty that 


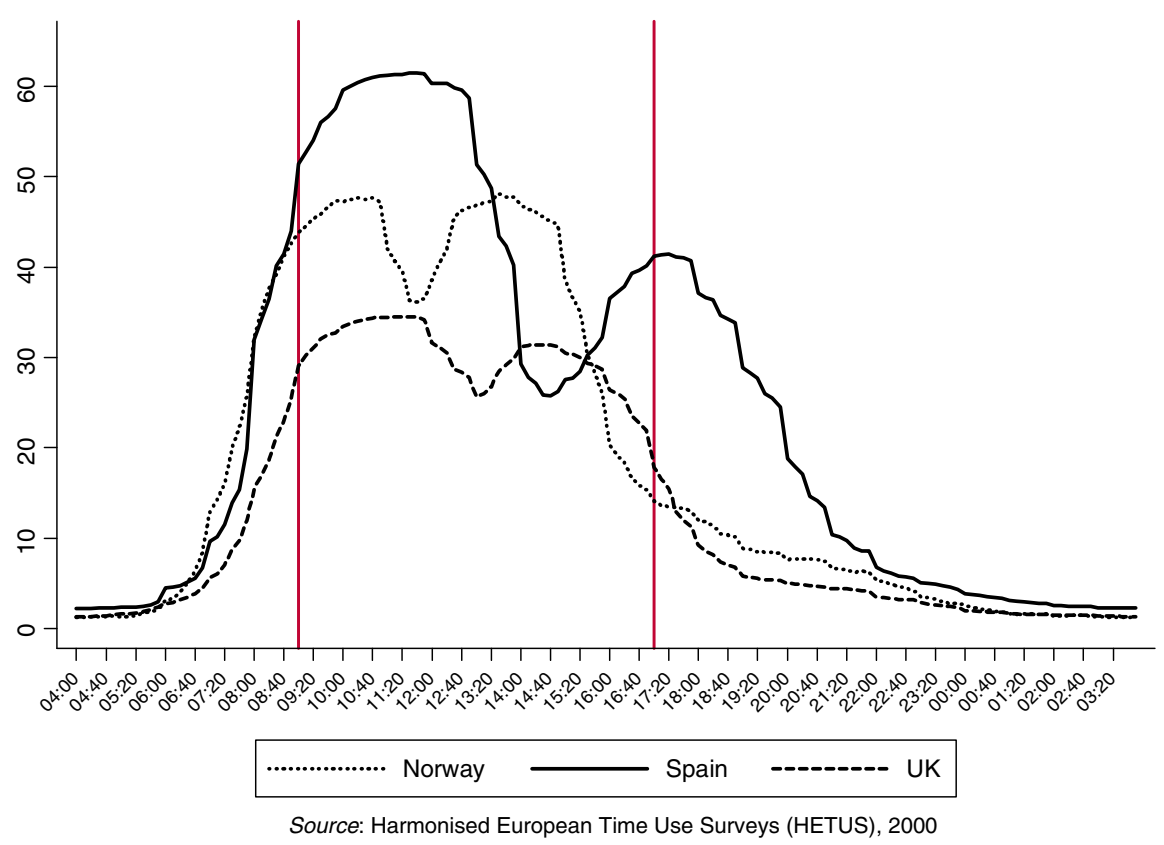

Fig. 1 Distributions of the timing of work in various European countries

part-timers face in finding full-time jobs (which contrasts with the Netherlands where workers seem to voluntarily choose to work part-time). Furthermore, in Spain females are 2.6 times less likely than males to switch from part- to full-time employment, whereas Dutch females are not less likely than their male counterparts to increase the number of hours they work.

Finally, another possible impediment of female employment is the way the work day is organized in Spain. Work schedules in Spain are typically split and consist of $5 \mathrm{~h}$ of work in the morning (from 9 a.m. to 2 p.m.), followed by a $2 \mathrm{~h}$ break at lunch time and another $3 \mathrm{~h}$ of work in the afternoon/evening (from 4 p.m. to 7 p.m.). Figure 1 shows the fraction of adult population (ages 16 and above) who work at a given time of the day in Norway, Spain and the UK in 2000. In all countries, a very small fraction of the population is at work before $8.00 \mathrm{a} . \mathrm{m}$. and the fraction is highest between 9.00 a.m. and 16.00 p.m.. There are two features that distinguish Spain from the other two countries. First, a larger fraction of people have a lunch break. Second, while in the other countries a very small fraction, less than $10 \%$, is still working at 6.00 p.m., almost $40 \%$ of the population is still at work in Spain. The picture is very similar if one looks at males and females separately. The split work schedule and longer hours imply additional costs for parents. Comparing workers with different work schedules in Spain, Amuedo-Dorantes and De la Rica (2006) find that most women are constrained in their work schedules, i.e. they would rather work a continuous schedule, and do not find evidence of a compensating wage differential for having a split work schedule.

Cash Benefits for Working Mothers and Children: With the aim of reconciling family and work, a monthly cash benefit for working mothers of children aged less 
than three years old was introduced in 2003 (Ley 46/2002 de 18 de diciembre de 2002). The monthly cash benefit amounted to 100 Euros per child aged less than three years old. To be eligible, working mothers must fulfill certain conditions in relation to the number of hours worked. ${ }^{9}$ The cash benefit is sizeable; it represents about $30 \%$ of the average cost of private day-care centers in Spain. Compared to the working females' observed earnings, it is about $13 \%$ of a primary educated female's monthly earnings, $8 \%$ of a secondary educated one or $5 \%$ of a college educated one. ${ }^{10}$ The 2003 reform also increased the tax deduction for children.

Sánchez-Mangas and Sánchez-Marcos (2008) show that cash benefits indeed led to a $5 \%$ increase in the employment rate of eligible women and the effect was more pronounced among less educated women. Azmat and González (2010) also explore the effect of the combined policy (of cash benefits and higher tax deductions) on fertility and mothers' employment. They estimate policy changes increased birth rates by about $5 \%$ (or by about three births per 1,000 women) and employment of mothers with children under three by about $2 \%$. By allowing women to work and accumulate labor market experience, this policy might also have longer-run effects on female employment that are difficult to measure.

\subsection{Other institutional changes}

Changing Divorce Laws: It was not until 1981 that divorce was legalized (Ley 30/1981) in Spain and although there were some marital separations before the law had been passed, they were rare. More recently, a reform of the law established unilateral divorce in 2005 (Ley 15/2005). As a consequence of these laws the cost of marital dissolution has gone down over the last decades, the crude divorce rate increased from 0.3 divorces per 1000 in 1981 to 2.2 divorces per 1000 in $2010 .^{11}$

Several papers in the literature found a positive impact of marital dissolution risk on women's employment using reduced form analysis for the United States (see, among others, Johnson and Skinner (1986), Sander (1985), Parkman (1992), Sen (2000)). In the context of a structural model, Caucutt et al. (2002) explore how married women consider the effect of motherhood and labor supply on the prospects of future outside-marriage options once divorce is allowed and find that this is important in order to understand labor supply and fertility patterns in the United States. Hence, it is reasonable to expect that the series of reforms concerning marital dissolution might be one of the factors behind the transition in female employment and fertility

\footnotetext{
9 These conditions differ for full-time and part-time working mothers. In particular, full-time female workers must work at least 15 days per month. For part-time female workers the equivalent figure is 20 days. Furthermore, part-time female workers are eligible only if they work at least $50 \%$ of full-time hours. There is an upper limit to the cash benefit given by the annual social security payroll taxes, but the benefit is not income tested (see Ley 46/2002 de 18 de diciembre de 2002).

10 Families with children (whether the mother works or not) are also eligible for a cash benefit per child (Ley 24/1997) if the child is younger than 18 years old or if the child suffers from any type of disability. This subsidy is, however, means tested and the income threshold is quite low (about 7,000 Euros annual income in 2000).

11 Source: Eurostat Marriage and Divorce Statistics.
} 
decisions. Of course, divorce risk cannot be considered an exogenous shock. A higher female attachment to the labor force may have contributed to the increase in marital dissolutions, as it enhances outside-marriage opportunities for women.

The impact of divorce on female labor supply might depend on how property is divided upon divorce (Gray 1998; Stevenson 2008). Kapan (2008) studies the effect of a law implemented in 2000 in England and Wales that favored the financially disadvantaged spouse by entitling him/her to a higher share of total assets at divorce. Using the British Household Panel Survey 1991-2006, he finds that married women reduced their labor supply between 2 to $3 \mathrm{~h}$ per week after the law had changed. For Spain, Brassiolo (2012) studies the effect of changes in laws governing the division of family assets at divorce on the probability of divorce and on female labor supply in two regions of Spain (Catalonia and Balearic Islands). In these two regions, a 1993 reform introduced an economic compensation for the financially weaker spouse upon divorce. In 1998, however, another change allowed marital contracts to include provisions regulating the dissolution of marriage, possibly counterbalancing the reform of 1993. He finds that while the first change led to a decrease in female employment and working hours (as the provision improved the bargaining position of women within marriages), the second change was associated with higher employment and working hours.

Taxation: Several tax reforms have been undertaken in Spain since the personal income tax was introduced for the first time in 1979. Some of these reforms have potentially affected household decisions to some extent, particularly fertility and female labor supply. Until 1991 (Ley 18/91, de 6 de junio) married couples were required to file joint returns and, as a consequence, their incomes were subject to a higher marginal tax rate. However, a deduction from the tax liability for married households and an additional deduction for two-earner households were applied. As a result, married couples was treated asymmetrically depending on the number of earners. After this date, married couples were allowed to choose between joint and individual taxation. As it has been shown in Kaygusuz (2010) for the case of the US, this may have a substantial impact on female labor market participation. In fact, Gutiérrez-Domenech (2005) shows that the transition towards separate taxation has positively affected mothers' probability of post-birth employment in Spain. A second important change in tax policy took place in 1999 (Real Decreto 214/1999, de 5 de febrero) and changed how family structure affects tax calculations. Before 1999 there was a deduction from tax liabilities for dependent children. Since 1999 deductions for family size have been applied directly to taxable income, and the tax liability is calculated for household income net of deductions. As a result, tax savings per child is now increasing in the marginal tax rate. As we mentioned above, a reform in 2003 increased the tax deduction applied based on the number of children and the tax deduction for each child aged less than three years old. ${ }^{12}$ According to Azmat and González (2010) the effect of the increase in child deductions on mothers' employment was negative.

\footnotetext{
12 Before the policy, family annual taxable income was reduced by 1,200 euros each for the first and second child and by 1,800 for the third child and subsequent children. After the policy was introduced, families have been able to reduce their annual taxable income by 1,400 euros for the first child, 1,500 euros for the second child, 2,200 for the third child and, finally, 2,300 for each subsequent child. Furthermore, the tax deduction for having a child under 3 years went up from 300 to 1,200 euros per child.
} 
Affirmative Action Policies: In March 2007 the Spanish Government passed the Equality Law (Ley 3/2007, de 22 de marzo) imposing gender parity in all selection committees in the state administration, party lists and those firms and organizations depending on the public administration. ${ }^{13}$ The justification of such a policy lies on the potential discrimination against women by the evaluation committees. However, it is not obvious to what extent this type of measure would increase the chances of females filling top positions in the public sector. In fact, Bagues and Esteve-Volart (2010) analyze how the chances of success of 150,000 female and male candidates (from 1987 to 2007) for positions in the four main Corps of the Spanish Judiciary were affected by the gender composition of their evaluation committee. They find that a female (male) candidate was significantly less likely to be hired whenever she (he) was randomly assigned to a committee in which the share of female (male) evaluators was relatively greater. Their evidence suggests that this was related to the fact that female majority committees overestimated the quality of male candidates.

Contraceptive methods and abortion: As emphasized by Goldin and Katz (2002) among others, the ability of females to control their fertility decisions may have a substantial impact on their career planning and on fertility rates. During the dictatorship the use of contraceptive methods was penalized by law. This changed in 1978 (Real Decreto 2275/78 de 7 de octubre), and over the last three decades the use of contraceptive methods has been widely spread across the population to control fertility. The contraceptive prevalence rate (percentage of women who are practicing or whose sexual partners are practicing any form of contraception, usually measured for married women ages 15-49) went up from 54\% in 1983 to $76 \%$ in 1993, and today is comparable to other developed countries (Carro and Mira 2006). ${ }^{14}$ Additionally, the first Law regulating abortion in Spain was introduced in 1985 (Ley Orgánica 9/85 de 5 de julio 1985). According to this Law abortion was allowed only during the first three months of pregnancy and under certain circumstances, such as mother's health risk (either physical or mental), fetus risk or rape. It is not until March 2010 (Ley Orgánica 2/2010de 3 de marzo) that a new law was passed in the Parliament establishing that during the first 14 weeks of pregnancy women are free to interrupt a pregnancy. The number of abortions went up from about 20 thousand in 1987 to 112 thousand in $2012 .{ }^{15}$

Fertility subsidies: A universal child benefit was introduced in 2007 aimed at promoting fertility in Spain (Ley 35/2007, de 15 de noviembre). The one-time payment benefit of 2,500 euros, to be paid to the mother immediately after birth, was about 4.5 times the monthly gross minimum wage of a full-time worker. González (2013)

\footnotetext{
13 Private corporations also received governmental guidelines in order to increase participation of women on boards.

14 Carro and Mira (2006) estimate a dynamic stochastic discrete choice model of contraceptive decisions. They show that an exogenous delay in the age of marriage can substantially reduce fertility. In particular, an increase in the age of marriage, from age 23 to ages 27 or 30 reduces the expected number of births from 2.08 to 1.86 or 1.65 , respectively.

15 According to the Ministerio de Sanidad, Instituto Nacional de Estadística and Johnston archive (http:// www.johnstonsarchive.net/policy/abortion/).
} 


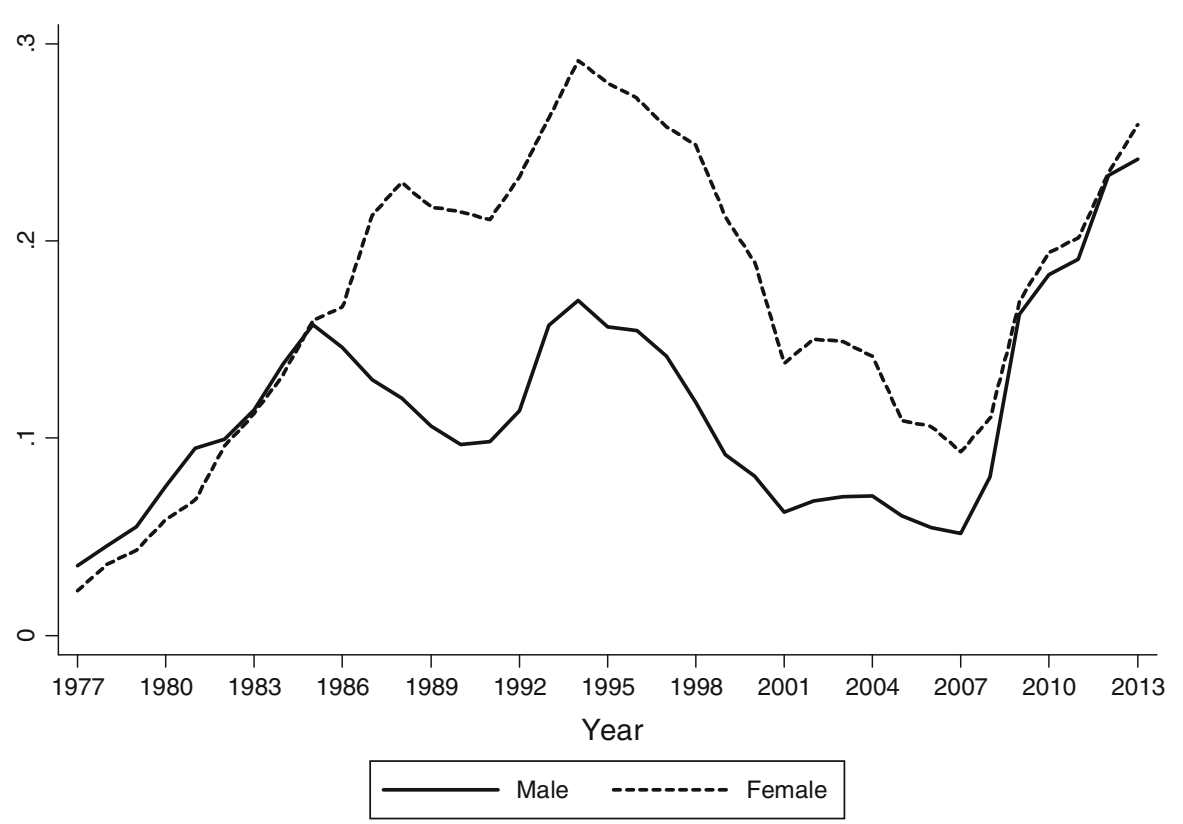

Source: Encuesta de Población Activa (EPA), 1977-2013

Fig. 2 Unemployment rate

finds that annual number of births increased by about 6 percent as a result of the policy. This was in part through a reduction in abortions. Eligible mothers also stayed out of the labor force longer after childbirth, which led to their children spending less time in formal child care.

\section{Gender gaps}

The aim of this section is to provide a detailed picture of gender gaps in employment and wages in Spain, and document how they evolved in recent decades. Before presenting an account of gender gaps, however, we first discuss two key features of Spanish labor markets. First, during the last few decades the unemployment rate has been quite high (it averaged about $12 \%$ for men and $18 \%$ for women between 1977 and 2013) and exhibited large fluctuations, reaching above $20 \%$ during recessions in the late $1980 \mathrm{~s}$ and early 1990s (Fig. 2). ${ }^{16}$ Females are much more likely to be unemployed than males, the unemployment rate of females was twice as high as that of males. ${ }^{17}$ This pattern changed in the last recession as the male unemployment rate increased more

\footnotetext{
16 See Berge and Jorda (2013) for a chronology of Spanish business cycles.

17 According to Azmat et al. (2006), the gender gap in unemployment in Spain was the highest among the OECD countries in 1999. They find that there is a gender gap in both flows from employment into unemployment and from unemployment into employment, and that differences in human capital accumulation between men and women interacted with labor market institutions is important to account for these differences.
} 


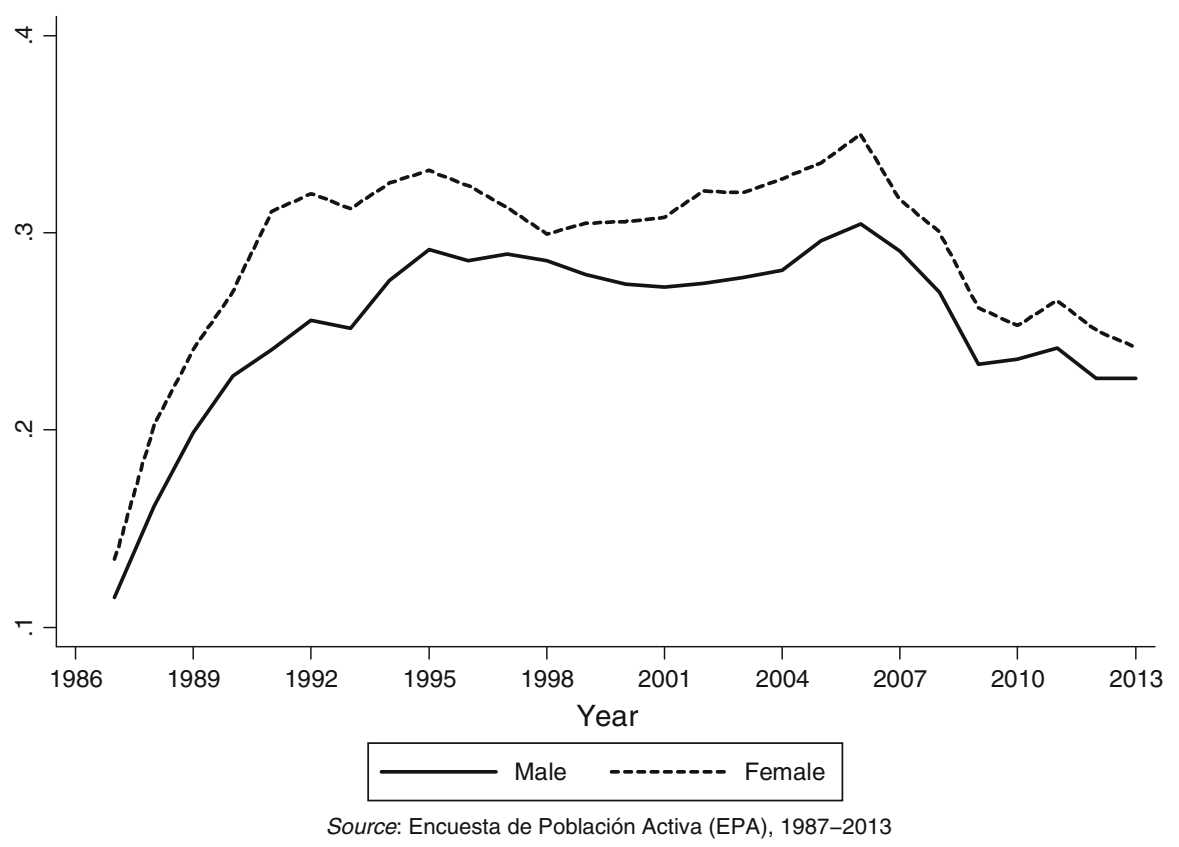

Fig. 3 Fraction of temporary workers

than the female unemployment rate and they were essentially identical by $2013 .{ }^{18}$ Second, as Fig. 3 shows, the fraction of temporary (fixed-term) workers has grown since the end of the eighties as a result of a series of labor market reforms that were introduced to combat unemployment. ${ }^{19}$ In 2008 the fraction of the labor force with temporary contracts was $29.3 \%$ in Spain, while the OECD average was only $11.8 \%$ (OECD 2010a). Furthermore, the incidence of temporary contracts among women is higher than among men. The last recession decreased the fraction of temporary contracts as most of the adjustment in the labor force was made through workers with temporary contracts that have much lower firing costs. ${ }^{20}$ The overall increase in the prevalence of temporary contracts since the end of the eighties implies an increase in employment and income uncertainty that households face during the period of analysis. This uncertainty was somehow mitigated by the large increase in public sector

\footnotetext{
18 A similar pattern is also observed in the U.S.—see Sahin et al. (2010).

19 In 1984 the Labor Law Reform relaxed the conditions for firms to hire workers under fixed term contracts. Firms could hire fixed-term employees subject to a severance pay of 12 days' wages per year of service for any kind of job (with contract duration between 6 months and 3 years and compulsory conversion into permanent thereafter). Workers with permanent contracts are entitled to severance pay of 20 days' wages per year of service (up to a maximum of 12 months' wages) in fair dismissals and to 45 days' (up to a maximum of 42 months') wages in unfair dismissals. In spite of several reforms (in 1994, 1997, 2002, and 2006) aimed at fighting the prevalence of temporary employment, the fraction of temporary contracts in the mid-2000s was above $30 \%$.
}

20 See Bentolila et al. (2010) and Costain et al. (2010) for an analysis of the role of temporary contracts in the last recession in Spain. 


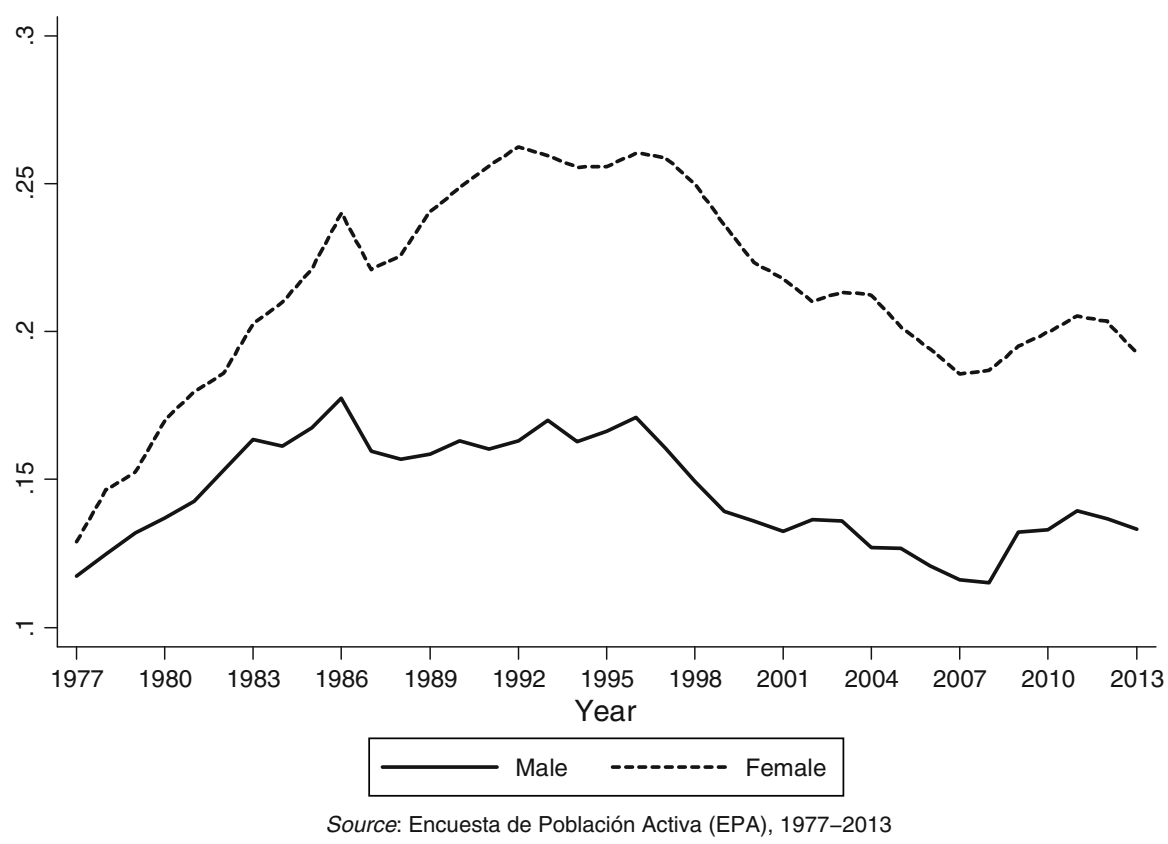

Fig. 4 Fraction of workers in the public sector

employment up to the early 1990s, but since then there has been a significant drop in public sector employment, further exacerbating the uncertainties that women face in the labor market (see Fig. 4).

\subsection{Employment}

In order to document gender employment gaps and their evolution over time, we use the Encuesta de Población Activa (EPA) data, from 1977 to 2013. These surveys are run by the Instituto Nacional de Estadística (INE), the Spanish Statistical Agency, and constitute the Spanish part of Labor Force Statistics of OECD. Each survey consists of a representative sample of about 60,000 households and contains labor market information of all individuals older than 16 that belong to each household. Although the information on labor market outcomes is quite detailed; the surveys do not contain information on wages. ${ }^{21}$ We focus on individuals between ages 25 and 54 in order to concentrate on individuals who have already completed their education and to leave aside the effect of early retirement decisions on employment (an important feature of the Spanish labor market). ${ }^{22}$

21 Although there have been some methodological changes over the period of analysis, as documented by Cuadrado et al. (2007), the basic structure of EPA remained unchanged over this period.

22 See García-Pérez et al. (2010). 


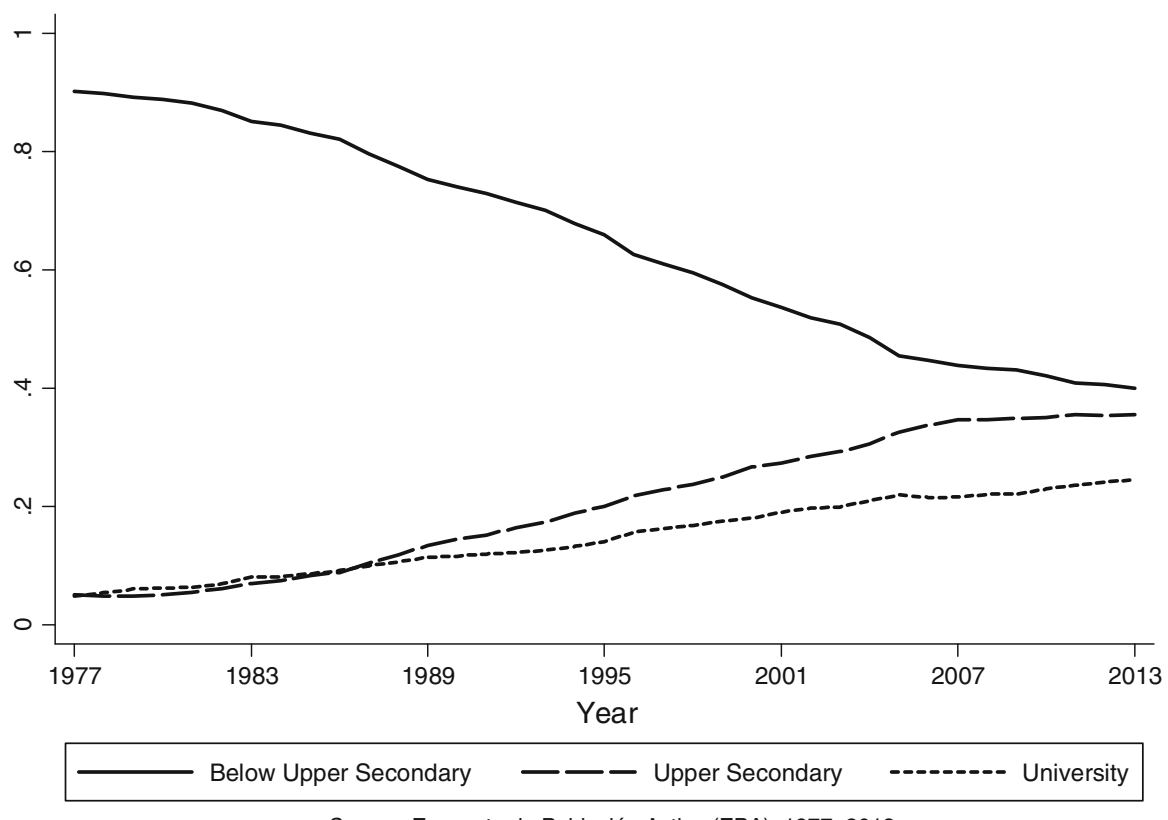

Source: Encuesta de Población Activa (EPA), 1977-2013

Fig. 5 Educational attainment

\subsubsection{Cross sectional analysis}

We start by documenting cross-sectional changes in the educational attainment of the population, employment and unemployment rates, and hours of work for men and women. The most remarkable change during this period was the increase in the educational attainment. As Fig. 5 documents, about $80 \%$ of the population had less than upper secondary education (high school) by the end of the 1970s. In 2013, the population with less than upper secondary education declined to $43 \%$, and about $23 \%$ of the population had a college degree (more than four times the level at the beginning of the period). Indeed, by the end of the sample period, the fraction of the population with tertiary education in Spain reached levels similar to the OECD average, about $28 \%$ in 2008 (OECD 2010b). ${ }^{23}$ The fraction of the population with less than upper secondary education is, however, about 20 percentage points higher (and correspondingly the fraction of individuals with upper secondary education is 20 percentage points lower) than the OECD average (OECD 2010b).

It is quite remarkable that the college attainment gender gap (ratio of women to men with college education) has also declined and was eventually reversed, from 0.6 in 1977 to 1.4 in $2013 .{ }^{24}$ However, there are still substantial gender differences in

\footnotetext{
23 Tertiary education includes not only college education but also other programs that focus on practical, technical or occupational skills for direct entry into the labor market. As a result, the fraction of the population with tertiary education is higher than the fraction with a university degree.

24 According to OECD (2010b), the tertiary education gender gap was 0.97 in 2010.
} 
the college degrees that are pursued by men and women. According to the Instituto Nacional de Estadística (INE), more than $80 \%$ of those who were registered in college degrees related to "Teaching" were women, whereas the figure was lower than $30 \%$ in those college degrees related to "Engineering". 25

Together with educational attainment, the female employment rate (employment to population ratio) increased dramatically over this period, whereas male employment rate declined slightly (Fig. 6a). In 1977, about $28 \%$ of women between ages of 25 and 54 worked, while by the end of the sample period more than $61 \%$ of them did so. With the increase in the female employment rate, the gender employment gap was reduced from $65 \%$ in 1977 to $9 \%$ in 2013. As we noted above, the last recession had an asymmetric effect on men and women. In particular, men were more likely to lose their jobs. As a result, part of the decline in the gender employment gap might be transitory, reflecting particular effects of the recent crisis on labor markets. In contrast to the gap in employment, the gender gap in hours worked (conditional on working) has been widening over this period and in particular since the 1990s (Fig. 7a). In 1977, men worked on average about $5 \mathrm{~h}$ per week more than women, while the gap was about $7 \mathrm{~h}$ in 2013. This reflects the fact that some fraction of women who entered the labor force took part-time jobs. Figure $6 \mathrm{~b}$ shows that females are more likely to be working in part time jobs than males and that the gap has been increasing in recent years. ${ }^{26}$ In $2013,26 \%$ of females were working part-time in contrast with $7 \%$ for males. $^{27}$ As Fig. $7 \mathrm{~b}$ shows, however, there has also been a slight widening of the gap between working hours of full-time workers, further contributing to the increasing gender gap in hours worked.

We next look at changes in employment rates conditional on educational attainment, marital status and the number of children to understand whether changes in female employment were driven by the behavior of some specific groups. One of the driving forces of the changes in female employment rate could be the change in educational composition of the female population, as there are substantial differences in employment rates across educational groups. Figure 8a shows, however, that the female employment rate increased for all educational levels, and that the increase is indeed more prominent for women with less than upper secondary education. During the period of analysis, with the changing patterns of marriage and fertility, women also became more likely to be unmarried or married without any children in recent years. The fraction of married women in our sample decreases from 84 to $60 \%$, and the fraction of unmarried mothers in our sample increased from 4 to $17 \%$ between 1977 and 2013. Since unmarried women and women without any children are more likely to work, this could have important implications for the average behavior. The

\footnotetext{
25 See Estadística de Enseñanza Universitaria 2008/2009, published by INE (http://www.ine.es/inebmenu/ mnu_educa.htm).

26 The increase in the fraction of part-time contracts in 2005 is due to changes in the survey questions of the Labor Force Survey carried out by the Statistical Institute. In particular, new questions were included in the survey aimed at identifying individuals working fewer hours.

27 Still, the incidence of part-time employment is quite lower than in other EU countries. In 2009, part-time employment as a fraction of total employment was about $21 \%$ in Spain, whereas it was above $30 \%$ in most of the EU countries (OECD 2010c).
} 

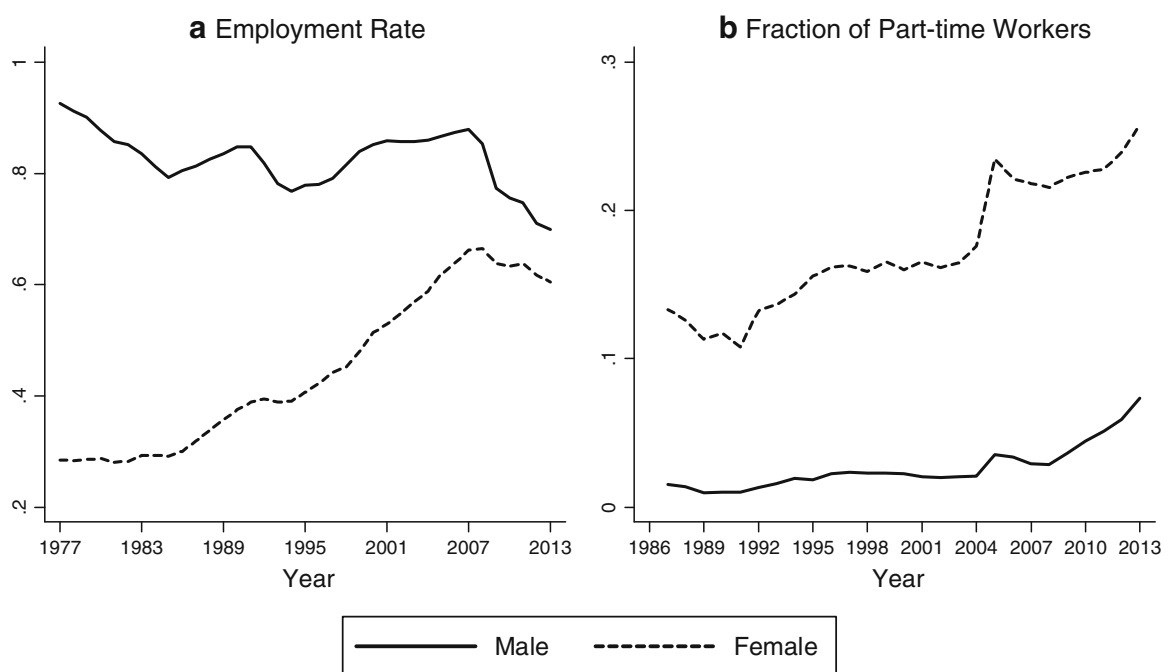

Source: Encuesta de Población Activa (EPA), 1977-2013

Fig. 6 Employment rate and fraction of part-time workers
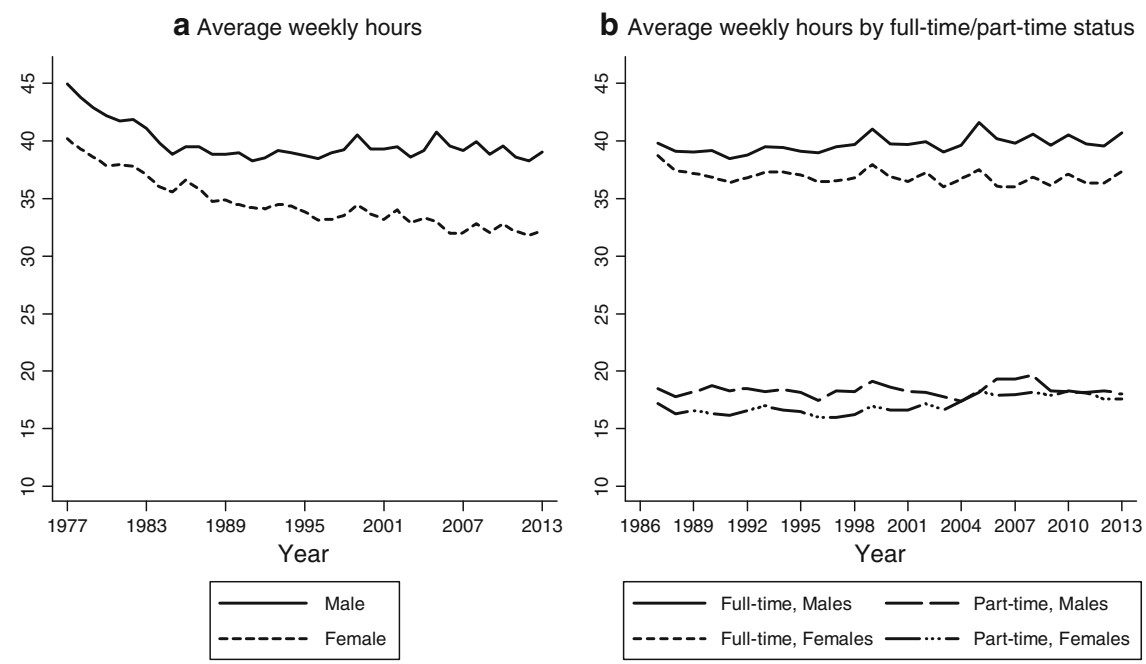

Source: Encuesta de Población Activa (EPA), 1977-2013

Fig. 7 Workers's average weekly hours of work

increase in the overall employment rate of females, however, has been mainly driven by the increase in the employment rate of married females (Fig. 8b). Their employment rate increased from $22 \%$ in 1977 to $59 \%$ in 2013. Furthermore, the increase in females' (married and unmarried) employment rate is independent of the number of children they have (Fig. 8c). Even for females with more than 2 children, the employment rate increased from 18 to $49 \%$. The employment rate of mothers also seems to 
be independent of the age of their youngest child (Fig. 9). ${ }^{28}$ Since there has been a significant change in the educational attainment of the female population, it is more informative to look at the employment rate conditioning on education. As Fig. 9b$\mathrm{d}$ show, for females with college education the increase has been similar regardless of the age of the youngest child, whereas for those with less than college education the increase started earlier for mothers with children older than three and has been more pronounced. Furthermore, we observe that the increase for mothers of children younger than three starts in the mid-nineties, which coincides with a large increase in the enrolment rates of three-years-old children we detailed in Sect. 2.

The existing literature has focused on education and fertility as possible determinants of female employment. Arellano and Bover (1995) use a time series model of female labor force participation and conclude that the increase in women's education and the decrease in birth rates (after controlling for endogeneity by treating education and fertility endogenous) are the main factors underlying the increase in female labor supply during the period 1976-1991. Although these two factors (education and fertility) must certainly play an important role, as we have shown above, even when we condition on education and children, there has been a significant increase in female employment after 1990s. There is some further evidence that child bearing is an important determinant of female labor force participation. Gutiérrez-Domenech (2005) uses the Family and Fertility Survey produced by the United Nations to explore women's transitions from employment to non-employment after first birth in several European countries (Spain, Belgium, W. Germany, Italy and Sweden). She finds that Spain, together with Germany, are the countries that experienced the greatest drop in post-birth employment rates. Furthermore, the drop is persistent even 10 years after childbearing.

\subsubsection{Cohort analysis}

In order to provide a more comprehensive picture of female labor supply behavior, we now document life-cycle employment profiles for three cohorts of individuals. This is important since labor supply is a dynamic decision and low labor market attachment early in the working life may determine labor market participation later on, due to returns to labor market experience and depreciation of human capital. ${ }^{29}$ As a result, changes in working conditions might affect female behavior with a delay. We focus on three cohorts and compare the behavior of those born at the beginning of the fifties (between 1950 and 1954), to those born at the beginning of the sixties (between 1960 and 1964) and those born at the beginning of seventies (between 1970 and 1974). We are able to observe the first (oldest) cohort from ages 25 to 55, the second cohort from ages 25 to 50 and the third (youngest) cohort from ages 25 to 40 . As Fig. 10a

\footnotetext{
28 This is in contrast with what we observe in other countries, where there are significant differences between the employments rate of mothers of children aged 0 to 3 and mothers with older children. According to the OECD (2007) Spanish females' employment rate gap with respect to the average of the OECD countries was 2.8 percentage points. However, the gap is increasing with the age of the youngest child. It ranges from 1.3 percentage points if the youngest child is younger than 2 , to 6.9 if the child is 3 to 5 years old, and to 15.6 if the child is 6 to 16 years old.

29 See Olivetti (2006) and Miller (2011) on the effects of career interruptions on female wages.
} 

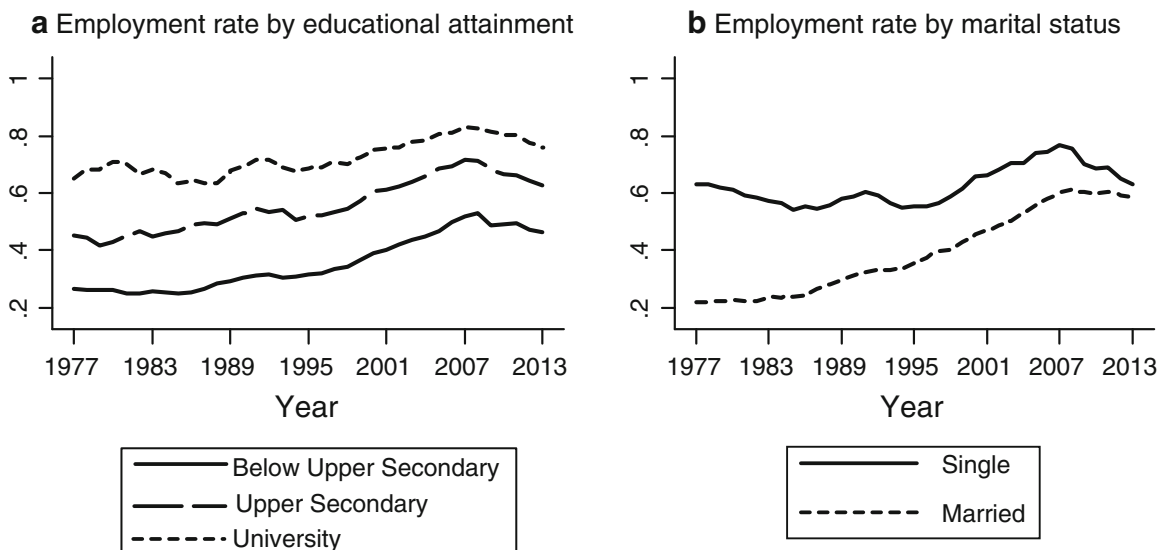

c Employment rate by the number of children
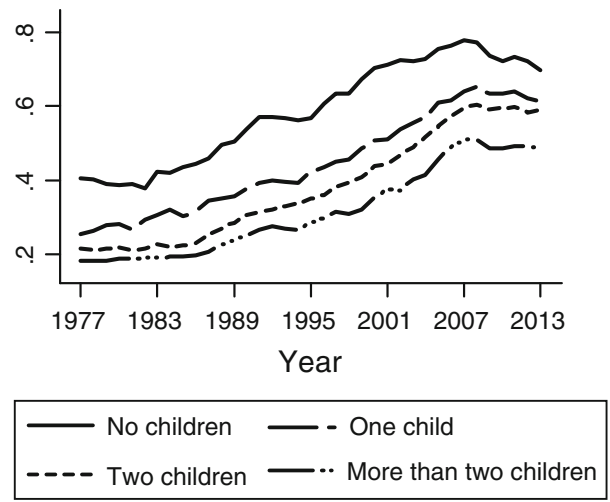

Source: Encuesta de Población Activa (EPA), 1977-2013

Fig. 8 Employment rate of females

shows, life-cycle labor supply behavior of these three cohorts of females differ quite significantly.

First, the three cohorts differ both in terms of labor market attachment and in how their labor supply changes with age. Females in cohort 2 are more likely to work than those in cohort 1 at any age and cohort 3 is more likely to work than cohort $2 .{ }^{30}$ Furthermore, for cohort 1 there is an important decline in employment rates during child bearing ages, while this decline is much less visible for cohort 2 and disappears completely for the youngest cohort. Indeed a comparison of female and male lifecycle behavior for the youngest cohort shows that the shape of their employment-age profiles is very similar (Fig. 10). ${ }^{31}$ Figure 11a shows that it is among those women

\footnotetext{
30 Part of this increase from the second to the third cohort might simply reflect time effects, as the 1990s was a period of rapid growth.

31 See Attanasio et al. (2008) for a similar pattern in employment-age profiles in the U.S.
} 

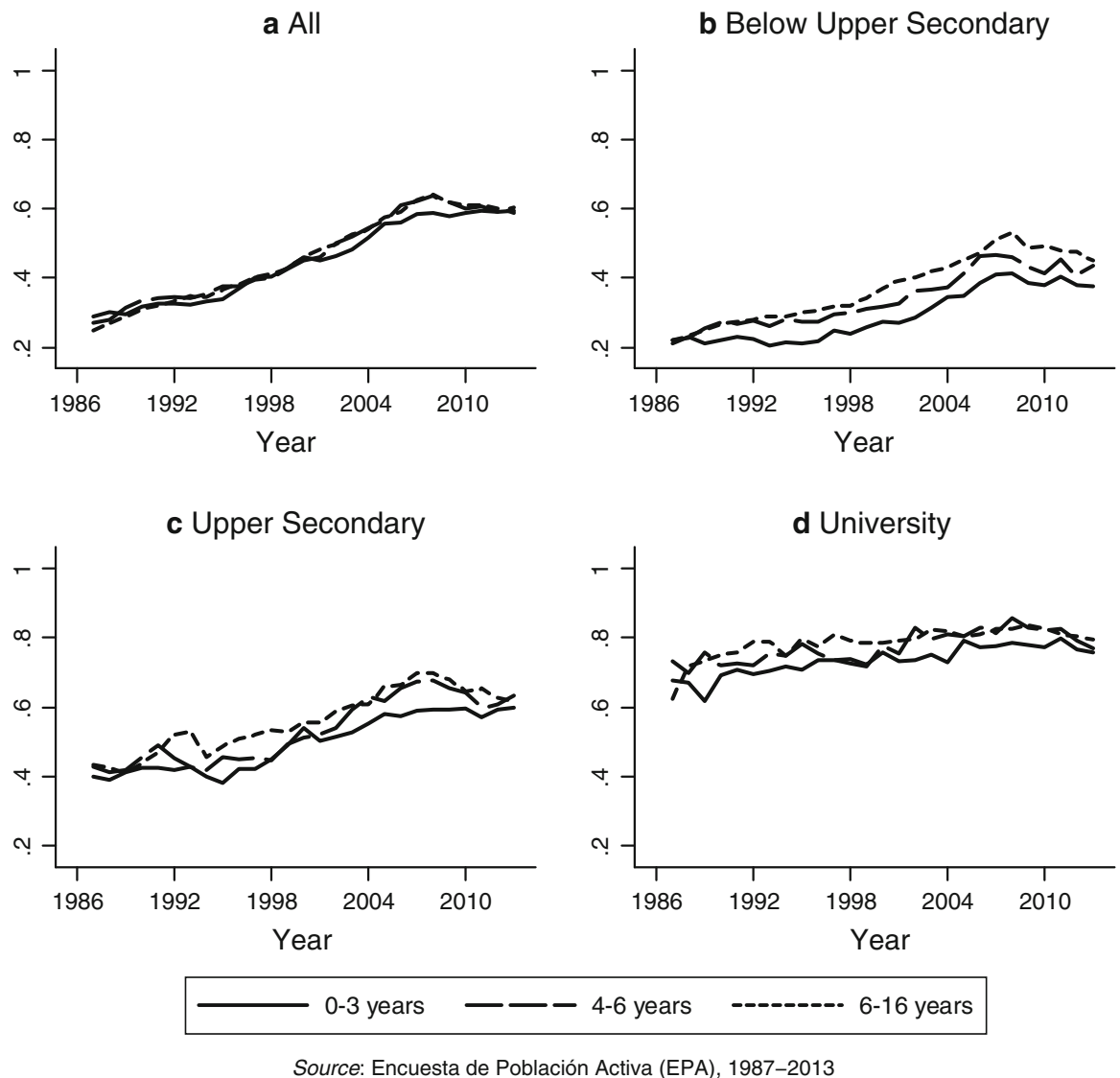

Fig. 9 Employment rate of mothers by age of the youngest child. The sample consists of 25-54 years old household heads and their partners and spouses

with upper secondary education or less where we observe more substantial differences across cohorts. Furthermore, the main difference between these cohorts originates in the behavior of married females (Fig. 12) and this is independent of the number of children they have (Fig. 13). Second, if we look at males, Fig. 10b shows that younger cohorts (cohorts 2 and 3 ) have much lower employment rates than cohort 1.

This reflects partly the delay in labor market entry of younger cohorts, as these cohorts are more educated than the older one. It also reflects the high level of youth unemployment in Spain. Finally, as Fig. 14 shows, whereas about $25 \%$ of women from cohort 1 and 2 benefited from working in the public sector since the beginning of their working life (the percentage is even higher later in life), the figure is lower than $15 \%$ for women who belong to cohort 3 .

An important difference between these three cohorts is their fertility behavior (both the number as well as the timing of children). Starting in the early 1980s, Spain experienced a dramatic decline in fertility. As Fig. 15a shows, the total number of births per 1,000 women aged 15-49 has declined from 80 to 40 between 1975 and 

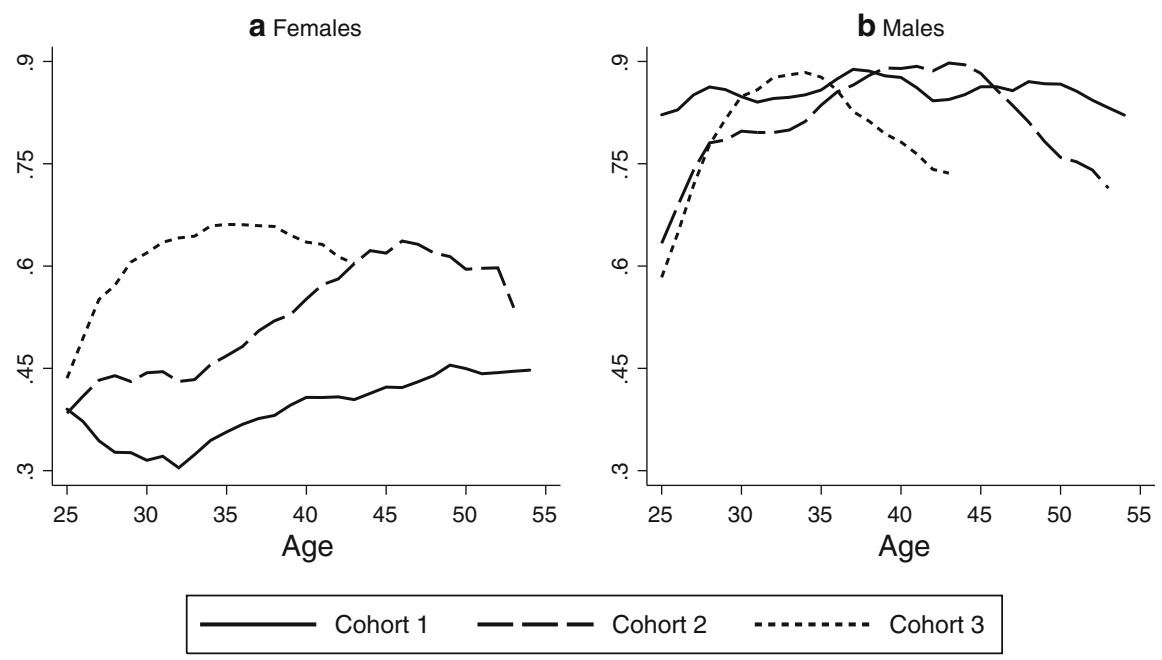

Source: Encuesta de Población Activa (EPA), 1977-2013

Fig. 10 Employment rates of cohorts. Cohort 1 born between 1950 and 1954, Cohort 2 born between 1960 and 1964, Cohort 3 born between 1970 and 1974

a Below Upper Secondary

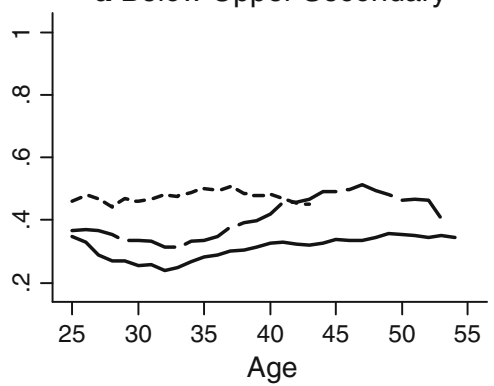

c University

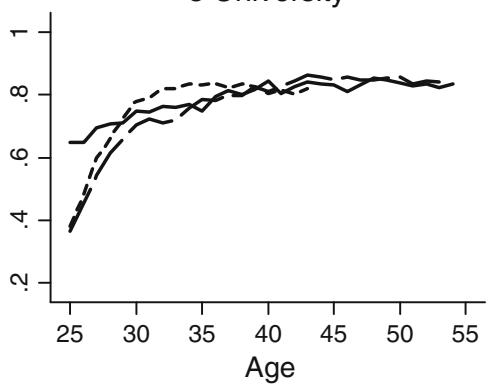

b Upper Secondary

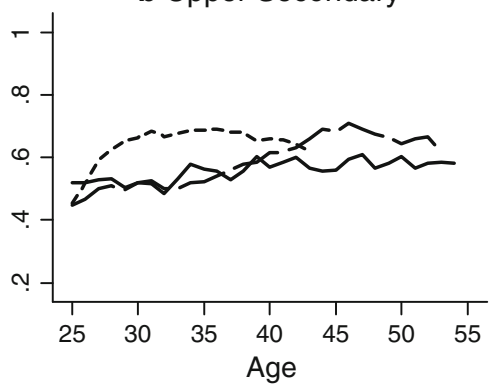

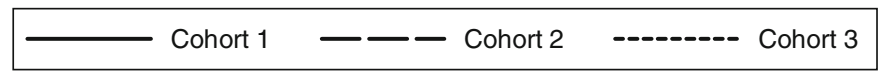

Source: Encuesta de Población Activa (EPA), 1977-2013

Fig. 11 Employment rates of cohorts of females by educational attainment. Cohort 1 born between 1950 and 1954, Cohort 2 born between 1960 and 1964, Cohort 3 born between 1970 and 1974 

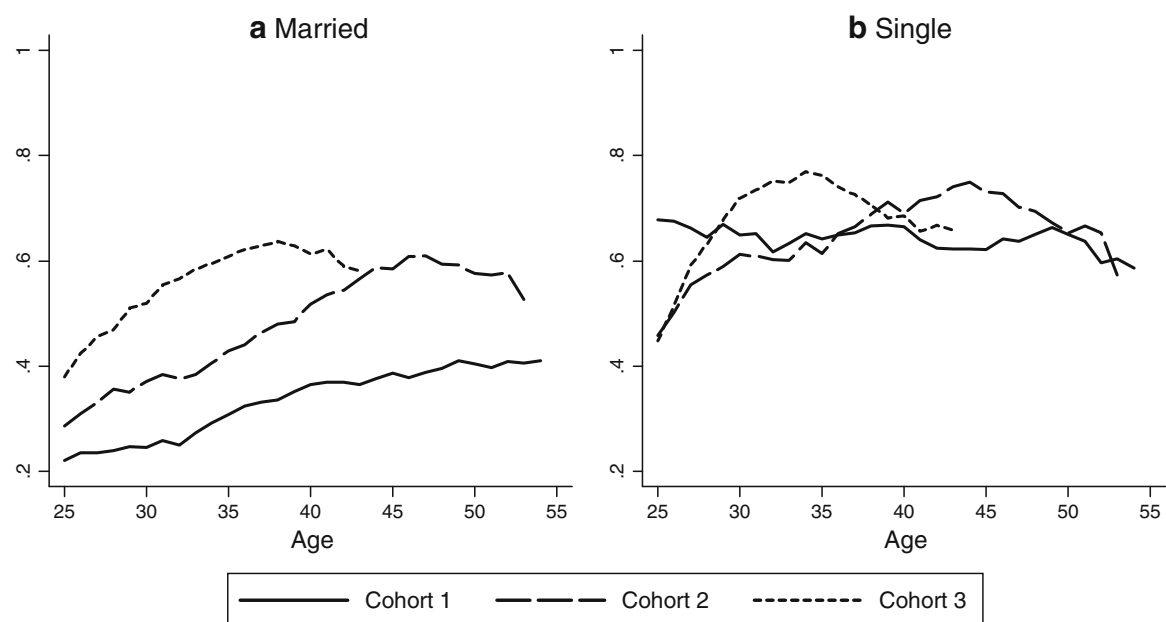

Source: Encuesta de Población Activa (EPA), 1977-2013

Fig. 12 Employment rate of cohorts of females by marital status. Cohort 1 born between 1950 and 1954 , Cohort 2 born between 1960 and 1964, Cohort 3 born between 1970 and 1974
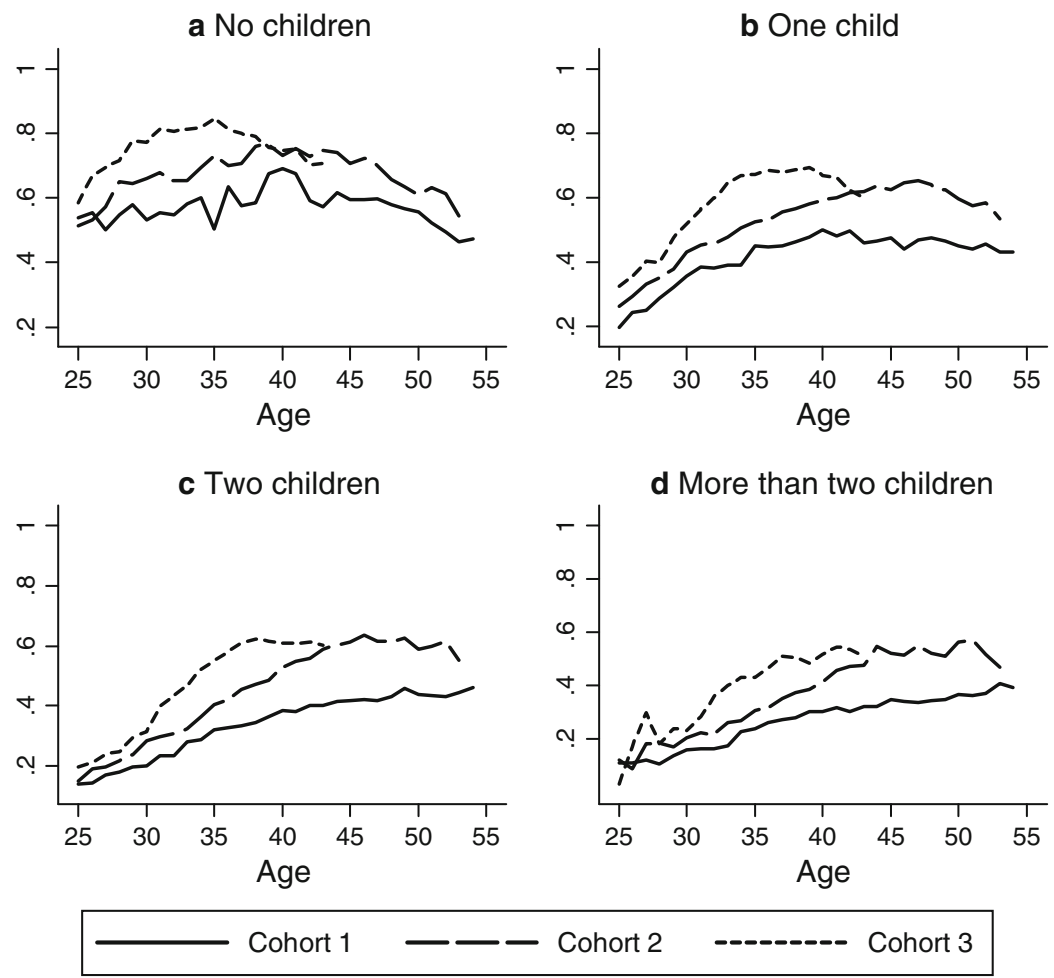

Source: Encuesta de Población Activa (EPA), 1977-2013

Fig. 13 Employment rate of cohorts of mothers by number of children. Cohort 1 born between 1950 and 1954, Cohort 2 born between 1960 and 1964, Cohort 3 born between 1970 and 1974 


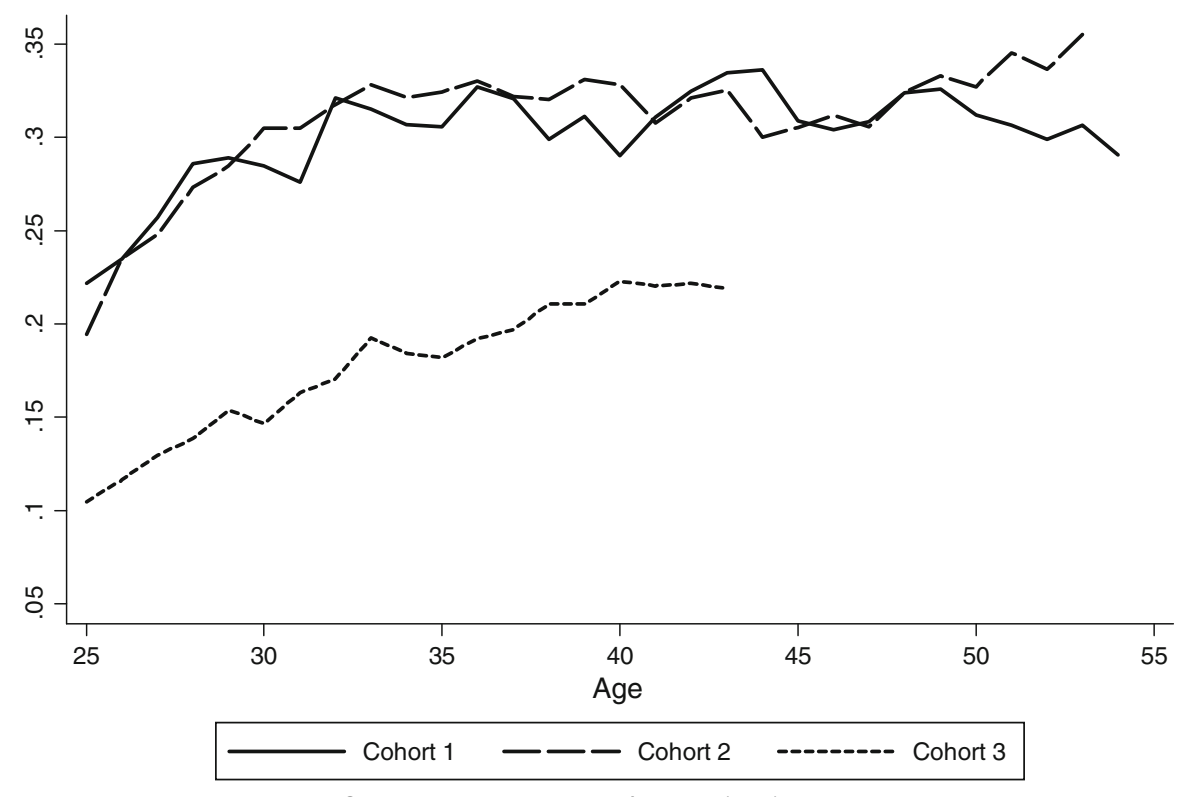

Source: Encuesta de Población Activa (EPA), 1977-2013

Fig. 14 Fraction of females working in the public sector by cohorts. Cohort 1 born between 1950 and 1954, Cohort 2 born between 1960 and 1964, Cohort 3 born between 1970 and 1974

1993 and has remained low since then. As a result, Spain had a very low (around 1.2) Total Fertility Rate (TFR) by the end of the 1990s, which has been reversed in recent years (TFR in 2007 was 1.4), mainly due to the large inflow of immigrants in the 2000s. ${ }^{32}$ As females started to have fewer children, they also started to have them later in life, and the mean age at first birth has increased from 25 years in 1977 to 29 years in 2007 (Fig. 15b). Part of this shift must reflect more widespread availability of contraception.

It is, however, not clear whether changing fertility patterns had an impact on female employment behavior. First, fertility started to decline in the mid 1970s (almost immediately after Spain's transition to democracy), while female employment started to grow about a decade later. Second, the literature that studies the interaction between fertility and labor market outcomes in Spain often concludes that it is the labor market that affects fertility behavior and not the other way around. Ahn and Mira (2001) estimate a discrete time hazard model of the probability of marriage and childbearing and conclude that the high incidence of unemployment and temporary jobs in Spain had a very strong negative effect on these outcomes. ${ }^{33}$ Da Rocha and Fuster (2006)

\footnotetext{
32 Source: http://www.oecd.org/els/familiesandchildren/40192107.pdf.

33 The negative impact of temporary contracts is also supported by the analysis in De la Rica and Iza (2005) and Adeserá (2006). Gutiérrez-Domenech (2008) finds that the increase in the incidence of unemployment among men tends to delay marriage and then fertility. Alba et al. (2009) estimate the causal effect of female labor market status on fertility using Spanish data. They find a positive although non-significant effect of participation and employment on the probability of having the first child, once the endogeneity is accounted
} 
a Number of births per 1000 women $15-49$ year old

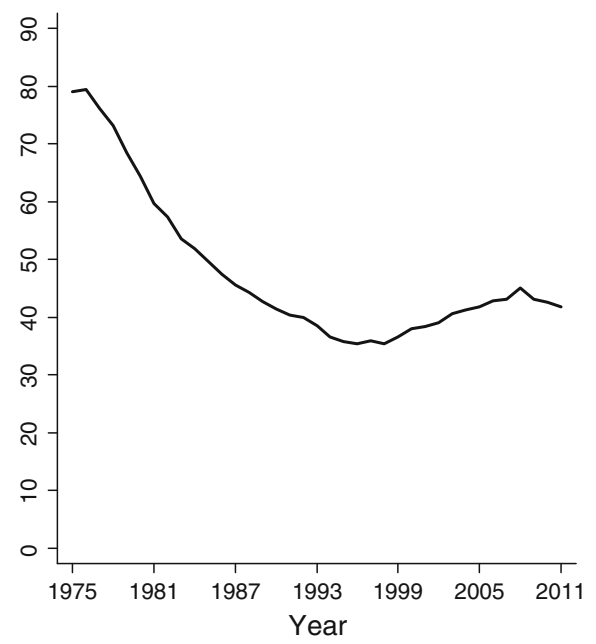

b Average age at first child birth

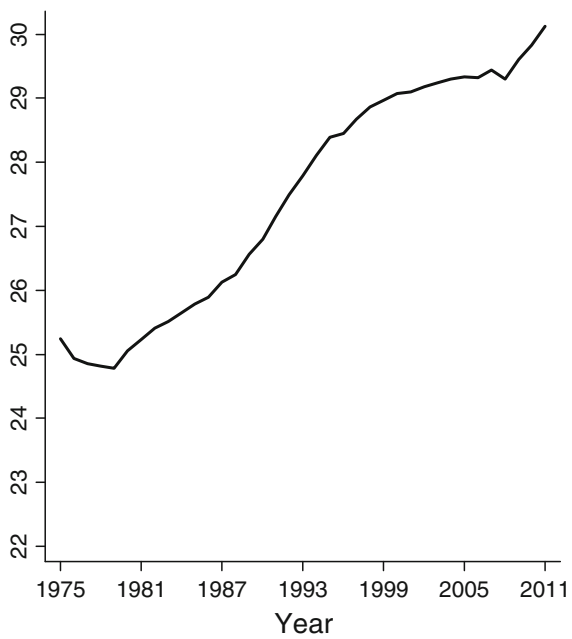

Source: Instituto Nacional de Estadística (INE), Main Demographic Indicators

Fig. 15 Number of births per 1,000 women (15-49 years old) and average age at first child birth

develop a quantitative theory of fertility and labor market participation decisions in order to explore the impact of labor market frictions (low probability of finding a job) on the observed positive correlation between fertility and employment among OECD countries. $^{34}$

\subsubsection{Do changes in the composition of population account for the increase in female employment rate?}

It is a challenging task to determine what the driving forces of these changes are. In principle, compositional changes in the population may account for at least a fraction of the increase in female employment rate. As we have seen, young cohorts of women are more educated, more likely to be unmarried and have fewer children, all factors that make them more likely to work.

Counterfactual Employment Levels: In order to gain some insight into the effects of compositional changes on the female employment rate we first carry out the following counterfactual exercise. The female employment rate was $25.0 \%$ in 1985 and $59.9 \%$

for using a switching probit model with endogenous switching. Finally, De la Rica and Ferrero (2003) estimate the effect of fertility on participation under the existence of unobserved characteristics that affect both fertility and participation (fertility decisions are endogenous to the participation decision) and find that the effect is negative and very strong.

34 Da Rocha and Fuster (2006) find that unemployment induces females to postpone and space births, resulting in a lower total fertility rate. Adeserá (2011) uses fluctuations in unemployment rates across European countries during the eighties and the nineties to investigate their effect on childbearing. She finds that high and persistent unemployment in a country is associated with delays in childbearing (and second births). 
Table 3 Employment rate under counterfactual distributions of observables

\begin{tabular}{lll}
\hline & Employment rate (\%) & $\begin{array}{l}\text { Difference with respect } \\
\text { to 1985 (\%) }\end{array}$ \\
\hline Data 1985 & 25.0 & 34.9 \\
Data 2005 & 59.9 & 12.5 \\
$\begin{array}{l}\text { Counterfactual rate in } 1985 \text { with education } \\
\quad \text { distribution of 2005 }\end{array}$ & 37.5 & 4.4 \\
$\begin{array}{l}\text { Counterfactual rate in } 1985 \text { with marital } \\
\text { status distribution of 2005 }\end{array}$ & 29.4 & 3.8 \\
$\begin{array}{l}\text { Counterfactual rate in 1985 with number of } \\
\text { children distribution of 2005 }\end{array}$ & 28.8 & 17.7 \\
$\begin{array}{l}\text { Counterfactual rate in 1985 with education, } \\
\text { marital status, and the number of children } \\
\text { distribution of 2005 }\end{array}$ & 42.7 & \\
\hline
\end{tabular}

Source Encuesta Poblacion Activa (EPA) 1985, 2005. Sample includes prime working age 25-54 heads of the household and partners or spouses of the heads

in $2005 .{ }^{35}$ We calculate what the employment rate in 2005 would be if the population had the educational attainment, marital status and the number of children of 2005 but faced the employment rates of 1985 . Table 3 shows that if only the distribution of education had changed, the employment rate in 2005 would have been $37.5 \%$. It would have been $29.4 \%$ if only the distribution of marital status had changed and, finally, $28.8 \%$ if only the distribution of number of children had changed. All the compositional changes together would have generated 17.7 additional percentages points of employment in 2005, about half of the actual increase since 1985. The rest potentially reflects other factors, such as the public policies and institutional changes outlined above.

Employment Regressions: We next estimate a linear probability model of the employment decision for the period 1977 to 2013. The results are reported in Table 4. We start in column I with a simple specification with a gender dummy variable that takes a value of one if the worker is female, a time trend, and a time trend interacted with the gender dummy variable. Then we progressively introduce different control variables that may be responsible for the employment rate gender gap as well as its trend. The coefficient of the gender dummy in regression I captures the average gross gender employment gap that we saw in the earlier figures, and the time trend interacted with the gender dummy reflects the closing gender gap pattern. Hence, on average females were about $66 \%$ less likely to be employed than males between 1977 and 2013, but this gap has been declining by about 1.5 percentage points every year. Results in columns II-VII, where we include different demographic controls, highlight different factors that contribute to the declining gender gap in employment.

First, the employment gap is larger for younger females (column II). Second, the gap is substantially higher for married women than for singles, and married women

\footnotetext{
35 We compare 1985 and 2005 because the increase in female labor supply started during the mid-eighties and we want to avoid the comparison with years affected by the last recession. Furthermore, for these counterfactuals we restrict the sample to heads of households and their partners and spouses. As a result the employment rates in Table 3 differ slightly from ones we have reported above.
} 
Table 4 Linear probability model for employment (1977-2013)

\begin{tabular}{|c|c|c|c|c|c|c|}
\hline & (I) & (II) & (III) & (IV) & $(\mathrm{V})$ & (VI) \\
\hline Female & $\begin{array}{c}-0.663^{* * *} \\
(0.001)\end{array}$ & $\begin{array}{c}-0.348^{* * *} \\
(0.005)\end{array}$ & $\begin{array}{c}-0.051^{* * *} \\
(0.005)\end{array}$ & $\begin{array}{c}-0.017^{* *} \\
(0.006)\end{array}$ & $\begin{array}{c}-0.124^{* * *} \\
(0.006)\end{array}$ & $\begin{array}{c}-0.112^{* * *} \\
(0.006)\end{array}$ \\
\hline Time trend & $\begin{array}{c}-0.002^{* * *} \\
(0.000)\end{array}$ & $\begin{array}{c}-0.003^{* * *} \\
(0.000)\end{array}$ & $\begin{array}{l}0.001^{* * *} \\
(0.000)\end{array}$ & $\begin{array}{l}0.001^{* * *} \\
(0.000)\end{array}$ & $\begin{array}{c}-0.001^{* * *} \\
(0.000)\end{array}$ & $\begin{array}{c}0.000 \\
(0.000)\end{array}$ \\
\hline Time trend $*$ female & $\begin{array}{l}0.015^{* * *} \\
(0.000)\end{array}$ & $\begin{array}{l}0.015^{* * *} \\
(0.000)\end{array}$ & $\begin{array}{l}0.003^{* * *} \\
(0.000)\end{array}$ & $\begin{array}{l}0.003^{* * *} \\
(0.000)\end{array}$ & $\begin{array}{c}0.000 \\
(0.000)\end{array}$ & $\begin{array}{c}-0.001^{* * *} \\
(0.000)\end{array}$ \\
\hline Age & & $\begin{array}{l}0.003^{* * *} \\
(0.000)\end{array}$ & $\begin{array}{c}-0.000^{* * *} \\
(0.000)\end{array}$ & $\begin{array}{r}-0.000 \\
(0.000)\end{array}$ & $\begin{array}{l}0.000^{* *} \\
(0.000)\end{array}$ & $\begin{array}{l}0.000^{* * *} \\
(0.000)\end{array}$ \\
\hline Age*time trend & & $\begin{array}{l}0.000^{* * *} \\
(0.000)\end{array}$ & $\begin{array}{c}-0.000^{* * *} \\
(0.000)\end{array}$ & $\begin{array}{c}-0.000^{* * *} \\
(0.000)\end{array}$ & $\begin{array}{c}-0.000^{* * *} \\
(0.000)\end{array}$ & $\begin{array}{c}-0.000^{* * *} \\
(0.000)\end{array}$ \\
\hline Age*female & & $\begin{array}{c}-0.008^{* * *} \\
(0.000)\end{array}$ & $\begin{array}{c}-0.003^{* * *} \\
(0.000)\end{array}$ & $\begin{array}{c}-0.003^{* * *} \\
(0.000)\end{array}$ & $\begin{array}{c}-0.002^{* * *} \\
(0.000)\end{array}$ & $\begin{array}{c}-0.002^{* * *} \\
(0.000)\end{array}$ \\
\hline $\begin{array}{l}\text { Age*time } \\
\text { trend*female }\end{array}$ & & $\begin{array}{c}-0.000^{* *} \\
(0.000)\end{array}$ & $\begin{array}{l}0.000^{* * *} \\
(0.000)\end{array}$ & $\begin{array}{l}0.000^{* * *} \\
(0.000)\end{array}$ & $\begin{array}{l}0.000^{* * *} \\
(0.000)\end{array}$ & $\begin{array}{l}0.000^{* * *} \\
(0.000)\end{array}$ \\
\hline Married & & & $\begin{array}{l}0.209^{* * *} \\
(0.002)\end{array}$ & $\begin{array}{l}0.208^{* * *} \\
(0.002)\end{array}$ & $\begin{array}{l}0.210^{* * *} \\
(0.002)\end{array}$ & $\begin{array}{l}0.209^{* * *} \\
(0.002)\end{array}$ \\
\hline $\begin{array}{l}\text { Married*time } \\
\text { trend }\end{array}$ & & & $\begin{array}{c}-0.001^{* * *} \\
(0.000)\end{array}$ & $\begin{array}{c}-0.001^{* * *} \\
(0.000)\end{array}$ & $\begin{array}{c}-0.001^{* * *} \\
(0.000)\end{array}$ & $\begin{array}{l}-0.001^{* * *} \\
(0.000)\end{array}$ \\
\hline Married*female & & & $\begin{array}{c}-0.593^{* * *} \\
(0.003)\end{array}$ & $\begin{array}{c}-0.593^{* * *} \\
(0.003)\end{array}$ & $\begin{array}{c}-0.543^{* * *} \\
(0.003)\end{array}$ & $\begin{array}{c}-0.542^{* * *} \\
(0.003)\end{array}$ \\
\hline $\begin{array}{l}\text { Married*time } \\
\text { trend*female }\end{array}$ & & & $\begin{array}{l}0.010^{* * *} \\
(0.000)\end{array}$ & $\begin{array}{l}0.010^{* * *} \\
(0.000)\end{array}$ & $\begin{array}{l}0.010^{* * *} \\
(0.000)\end{array}$ & $\begin{array}{l}0.009^{* * *} \\
(0.000)\end{array}$ \\
\hline Kids & & & & $\begin{array}{c}-0.014^{* * *} \\
(0.001)\end{array}$ & $\begin{array}{c}-0.015^{* * *} \\
(0.001)\end{array}$ & $\begin{array}{c}-0.013^{* * *} \\
(0.001)\end{array}$ \\
\hline Kids*time trend & & & & $\begin{array}{c}-0.000^{* * *} \\
(0.000)\end{array}$ & $\begin{array}{c}-0.000^{*} \\
(0.000)\end{array}$ & $\begin{array}{c}-0.000^{* * *} \\
(0.000)\end{array}$ \\
\hline Kids*female & & & & $\begin{array}{c}-0.007^{* * *} \\
(0.001)\end{array}$ & $\begin{array}{c}-0.006^{* * *} \\
(0.001)\end{array}$ & $\begin{array}{c}-0.008^{* * *} \\
(0.001)\end{array}$ \\
\hline $\begin{array}{l}\text { Kids*time } \\
\text { trend*female }\end{array}$ & & & & $\begin{array}{c}-0.001^{* * *} \\
(0.000)\end{array}$ & $\begin{array}{c}-0.001^{* * *} \\
(0.000)\end{array}$ & $\begin{array}{l}-0.001^{* * *} \\
(0.000)\end{array}$ \\
\hline Edu2 & & & & & $\begin{array}{l}0.048^{* * *} \\
(0.003)\end{array}$ & $\begin{array}{l}0.039^{* * *} \\
(0.003)\end{array}$ \\
\hline Edu3 & & & & & $\begin{array}{c}-0.017^{* * *} \\
(0.003)\end{array}$ & $\begin{array}{c}-0.020^{* * *} \\
(0.003)\end{array}$ \\
\hline Edu2*time trend & & & & & $\begin{array}{l}0.001^{* * *} \\
(0.000)\end{array}$ & $\begin{array}{l}0.002^{* * *} \\
(0.000)\end{array}$ \\
\hline Edu $3 *$ time trend & & & & & $\begin{array}{l}0.005^{* * *} \\
(0.000)\end{array}$ & $\begin{array}{l}0.005^{* * *} \\
(0.000)\end{array}$ \\
\hline Edu2*female & & & & & $\begin{array}{l}0.081^{* * *} \\
(0.004)\end{array}$ & $\begin{array}{l}0.087^{* * *} \\
(0.004)\end{array}$ \\
\hline
\end{tabular}


Table 4 continued

\begin{tabular}{|c|c|c|c|c|c|c|}
\hline & (I) & (II) & (III) & (IV) & $(\mathrm{V})$ & (VI) \\
\hline Edu $3 *$ female & & & & & $\begin{array}{l}0.332^{* * *} \\
(0.004)\end{array}$ & $\begin{array}{l}0.334^{* * *} \\
(0.004)\end{array}$ \\
\hline $\begin{array}{l}\text { Edu } 2 * \text { time } \\
\text { trend } * \text { female }\end{array}$ & & & & & $\begin{array}{l}0.000^{* *} \\
(0.000)\end{array}$ & $\begin{array}{c}0.000 \\
(0.000)\end{array}$ \\
\hline $\begin{array}{l}\text { Edu } 3 * \text { time } \\
\text { trend*female }\end{array}$ & & & & & $\begin{array}{c}-0.005^{* * *} \\
(0.000)\end{array}$ & $\begin{array}{c}-0.005^{* * *} \\
(0.000)\end{array}$ \\
\hline Immigrant & & & & & & $\begin{array}{l}0.250^{* * *} \\
(0.009)\end{array}$ \\
\hline $\begin{array}{l}\text { Immigrant*time } \\
\text { trend }\end{array}$ & & & & & & $\begin{array}{c}-0.011^{* * *} \\
(0.000)\end{array}$ \\
\hline Immigrant*female & & & & & & $\begin{array}{c}-0.211^{* * *} \\
(0.013)\end{array}$ \\
\hline $\begin{array}{l}\text { Immigrant*time } \\
\text { trend*female }\end{array}$ & & & & & & $\begin{array}{l}0.009^{* * *} \\
(0.000)\end{array}$ \\
\hline Constant & $\begin{array}{l}0.871^{* * *} \\
(0.001)\end{array}$ & $\begin{array}{l}0.769^{* * *} \\
(0.004)\end{array}$ & $\begin{array}{l}0.709^{* * *} \\
(0.004)\end{array}$ & $\begin{array}{l}0.736^{* * *} \\
(0.004)\end{array}$ & $\begin{array}{l}0.728^{* * *} \\
(0.004)\end{array}$ & $\begin{array}{l}0.713^{* * *} \\
(0.004)\end{array}$ \\
\hline $\begin{array}{l}\text { Number of } \\
\text { observations }\end{array}$ & 2690794 & 2690794 & 2690794 & 2690794 & 2690794 & 2690794 \\
\hline $\begin{array}{l}\text { Adjusted } \\
\text { Pseudo-R }\end{array}$ & 0.176 & 0.182 & 0.211 & 0.219 & 0.247 & 0.248 \\
\hline
\end{tabular}

Source Encuesta Poblacion Activa (EPA) 1977-2013. (i) The omitted category is taken as illiterate for education dummies. (ii) Standard errors are in parenthesis. $*$, ** and $* * *$ indicate significant at $0.01,0.05$ and 0.10 significance level respectively

are almost $60 \%$ less likely to be employed than single women (column III). The negative effect of marriage, however, has been declining over time. Third, the presence of children reduces employment probability for both men and women, but the effect is more pronounced for the latter (column IV). Furthermore, the negative effect of kids on females increased over time. ${ }^{36}$ Fourth, employment probability is increasing in female's education, and quite remarkably so for women with college education (column V). However, over the period of analysis the positive effect of female's college education decreases. Finally, while immigrants are about $25 \%$ more likely to be employed than natives, immigrant women are less likely to be employed than immigrant men (column VI). Hence, while immigrant women, as we mentioned above, might provide household services and allow highly-educated native women to work, there is a simple composition effect that increases gender employment gap. Immigrant women, however, are becoming more likely to be employed over time.

\footnotetext{
36 One should be careful in interpreting these numbers because of the potential endogeneity of the fertility decision, in particular given the dramatic changes in the total fertility rate that we documented for this period in the Spanish economy.
} 
While the estimated coefficient for the time trend interacted with the gender dummy is about 0.015 in the regression without demographic controls (column I), it declines to 0.003 when we also control for marital status (column III). The trend, however, is now captured in the variable that interacts the time trend with the married female dummy. Hence, married women are more likely to be employed over time during the period of analysis. This result is robust to the inclusion of other demographics. This suggests that there are other factors, apart from changes in demographics, that are behind the observed increasing trend of married female employment. Both policies that make employment more affordable and attractive for women as well as institutional/social changes, such as rise in divorce, that make women more willing to be attached to the labor market and build human capital, can be responsible for these trends.

\subsubsection{Occupational segregation}

Gender segregation across occupations or the tendency for men and women to be employed in different occupations is another important aspect of gender inequality. If men and women are employed in different occupations and if, for example, women are more concentrated in low-paying jobs, this will be reflected in gender wage equality, as we explore in Sect. 3.2. We study differences in the occupational distribution of men and women in Spain and the trends in gender segregation across occupations based on EPA from 1994 to 2013. ${ }^{37}$ In Table 5, the first column in each year displays the share of female workers within a particular occupation while female concentration represents the distribution of females across occupations for that year. ${ }^{38}$ As Table 5 documents, occupations in services such as clerical, service and sales, professional and elementary occupations gradually became female dominated in the Spanish labor market during these years. ${ }^{39}$ From 1994 to 2013 the share of female workers in these occupations increased by 15.6 percentage points for clerical occupations, 11.2 percentage points for services and sales, 8.7 percentage points for professionals and 15.4 percentage points for elementary occupations. Moreover, the largest share of the female labor force was employed in services and elementary occupations or in professional occupations in all years. On the other hand, women in the Spanish labor market seem to be less likely to work as skilled agricultural and fishery workers, craft and related trades workers, plant

\footnotetext{
37 In Spain, in 1993 and 1994 there were fundamental changes in the National Classification of Occupations, making it impossible to compare pre and post-1994 data. In order to guarantee the homogeneity of the occupation data and prevent errors that may arise from their re-classification, the period of analysis 19942013.

38 We focus on 1994, 2004 and 2010 since, as we document in the next section, these are the years for which we have data on wages.

39 Elementary occupations consist of simple and routine tasks which mainly require the use of handheld tools and often some physical effort, e.g. selling goods in streets and public places, or from door to door; providing various street services; cleaning, taking care of apartment houses, hotels, offices and other buildings, construction and manufacturing including product-sorting and simple hand-assembling of components, etc. Professionals include science, engineering, health, teaching, business organization, legal, social and human science professionals.
} 


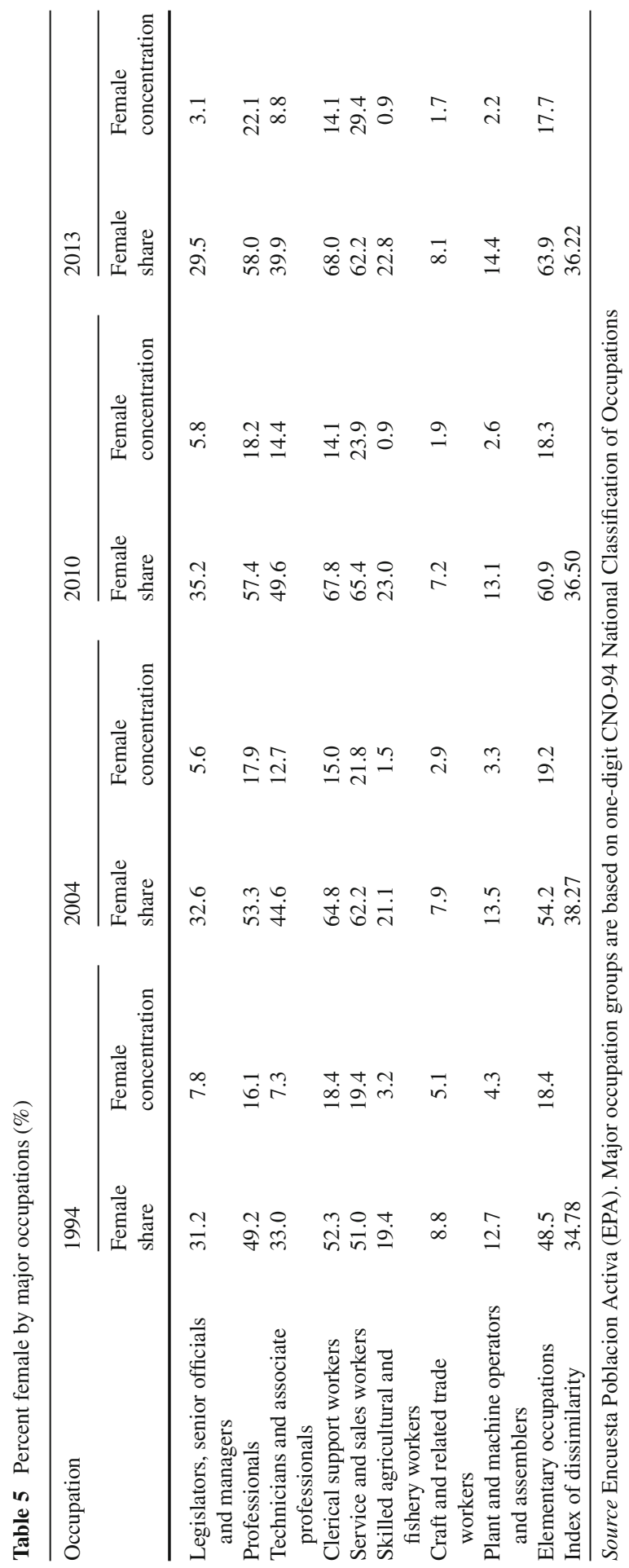


and machine operators or assemblers. This possibly reflects the decline of agriculture and manufacturing (sectors with male dominated occupations). ${ }^{40}$

A commonly-used measure of occupational segregation is the Duncan \& Duncan index of dissimilarity (ID), defined as

$$
I D_{t}=\frac{1}{2} \sum_{i=1}\left|m_{i t}-f_{i t}\right|,
$$

where $m_{i t}$ and $f_{i t}$ are the fractions of the male and female labor force employed in occupation $i$ at time $t .{ }^{41}$ The index is interpreted as the percentage of female and male workers that would have to change occupations in order for the employment distributions of men and women to be identical. In other words, a value of $0 \%$ indicates that the distribution of genders across occupations is identical, whereas a value of $100 \%$ implies that female and male workers were concentrated in completely different occupations. The Duncan and Duncan occupational segregation index was 34.78, 38.27, 36.50 and 36.22, for 1994, 2004, 2010 and 2013, respectively. The level of occupational segregation has been fairly stable and implies that more than one third of the male and female workers would have to change places across occupations so as to have a perfectly equal distribution.

Dolado et al. (2001, 2004) use the European Labor Force Survey (1999) and the Current Population Survey (1999) to examine the incidence and composition of female employment both in the EU and in the US in 1999 as well as the differences across age cohorts and educational levels. Their findings suggest that occupational segregation in the EU is higher than in the US for highly educated women, particularly for women aged 35-44, and Spain is not an exception. ${ }^{42}$ They also find that occupational segregation by gender is positively correlated with the share of part-time jobs in the economy. Interestingly, their results reveal some discriminatory forces behind this choice as the degree of job satisfaction by women is not high in part time jobs.

Brindusa et al. (2013) document a process of job polarization in recent years (19972012) in Spain. In particular, there has been an increase in the share of occupations at the low end of the wage distribution that cannot be accounted for changes in the composition of the labor force. This process has affected males more strongly than females since males have a higher concentration in occupations more intensive in routine tasks.

\subsection{Wages}

We analyze next gender wage gaps. According to the OECD, the observed gender wage gap in Spain was $11.8 \%$ in 2009 , clearly below the $15.8 \%$ average for the

\footnotetext{
40 Gender segregation in tasks or specializations can also be observed even within a given occupation. Dolado et al. (2012) study gender differences across research fields among academic economists.

41 For a discussion of this index, see Blau et al. (2002).

42 Moreover, their findings suggest that occupational segregation in Spain is much higher for the less educated women, with the dissimilarity index taking a value around 50 percent for all age groups. On the other hand, especially for the higher educated group the dissimilarity index is considerably higher for older women, implying less occupational segregation for younger highly educated women in Spain in 1999.
} 
Table 6 Descriptive statistics

\begin{tabular}{|c|c|c|c|c|c|c|}
\hline & \multicolumn{2}{|l|}{1994} & \multicolumn{2}{|l|}{2004} & \multicolumn{2}{|l|}{2010} \\
\hline & Female & Male & Female & Male & Female & Male \\
\hline Number of observations & 955 & 2060 & 3363 & 4654 & 3470 & 3929 \\
\hline Log hourly wage & $\begin{array}{l}1.944 \\
(0.550)\end{array}$ & $\begin{array}{l}2.018 \\
(0.514)\end{array}$ & $\begin{array}{l}1.892 \\
(0.495)\end{array}$ & $\begin{array}{l}2.040 \\
(0.497)\end{array}$ & $\begin{array}{l}2.161 \\
(0.456)\end{array}$ & $\begin{array}{l}2.239 \\
(0.444)\end{array}$ \\
\hline \multicolumn{7}{|l|}{ Education distribution (\%) } \\
\hline Below upper secondary & 40.8 & 54.4 & 30.6 & 43.6 & 23.7 & 35.4 \\
\hline Upper secondary & 20.7 & 18.2 & 22.9 & 22.8 & 22.6 & 24.8 \\
\hline University & 38.4 & 27.4 & 46.5 & 33.6 & 53.7 & 39.7 \\
\hline Immigrant & 3.2 & 1.3 & 6.2 & 6.8 & 8.3 & 10.1 \\
\hline Labor market experience & $\begin{array}{l}15.755 \\
(9.888)\end{array}$ & $\begin{array}{l}19.514 \\
(10.511)\end{array}$ & $\begin{array}{l}14.847 \\
(9.116)\end{array}$ & $\begin{array}{l}18.698 \\
(9.797)\end{array}$ & $\begin{array}{l}15.678 \\
(8.667)\end{array}$ & $\begin{array}{l}18.856 \\
(9.229)\end{array}$ \\
\hline Part-time $(\%)$ & 14.8 & 1.5 & 17.6 & 2.7 & 17.4 & 2.4 \\
\hline
\end{tabular}

Source For 1994 sample, European Community Household Panel (ECHP) and for 2004 and 2010 samples, European Union Statistics on Income and Living Conditions (EU-SILC) cross-sectional components

OECD countries. In this section we explore in detail the sources of this gap and its evolution from the mid-nineties to today. To this end, we use the first wave of European Community Household Panel (ECHP) for 1994, and the cross-sectional component of European Union Statistics on Income and Living Conditions (EU-SILC) for 2004 and 2010. ${ }^{43}$ We again focus on individuals of working age, between 25 and 54, with valid observations on all the variables used in the employment and wage equations. We exclude students, apprentices and the self-employed from the sample. For workers, we further restrict the sample to individuals who are working at least $15 \mathrm{~h} \mathrm{per} \mathrm{week.}{ }^{44}$ Table 6 provides the summary statistics for our sample. As we have already noted above, educational attainment of the population increased between 1994 and 2010, and there is now a larger fraction of females with a college degree. By the end of the sample period, about $10 \%$ of the workforce consists of immigrants. On average workers have between 15 (females) and 19 (males) years of labor market experience.

We start our analysis with standard Mincer regressions to isolate the mean gender wage differential that is not accounted for by gender differentials in individuals' observable characteristics (education, labor market experience, immigration status as well as part-time/full-time status, occupation and industry). Then, in order to compare male and female wages at different points of the wage distribution, we employ the quantile regression technique. Furthermore we also present the results of the Oaxaca (1973) decomposition based on the Mincer regressions to identify the separate effects

\footnotetext{
43 The advantage of using these surveys instead of the Encuesta de Estructura Salarial (EES), the Spanish Wage Structure Surveys, which is commonly used in the literature, is that the ECHP and EU-SILC allows us to correct for the sample selection bias that can very significant.

44 This restriction is necessary because of the nature of ECHP, since ECHP does not distinguish individuals regularly working less than $15 \mathrm{~h}$ from those out-of the labor force in the first two waves.
} 
of these observable factors on gender wage differentials as well as the results of the Machado and Mata (2005) decomposition based on the quantile regression estimates. Finally, since participation in the labor market is not random, we try to control for selection to obtain unbiased estimates of the gender wage gap. To this end, we estimate a reduced-form model of the participation decision and then use Heckman's correction in the regressions for wages.

Mincer regressions: Our empirical specification is given by

$$
\begin{aligned}
\text { lnWage }= & \beta_{0}+\beta_{1} \text { Female }+\sum_{i=2}^{3} \beta_{i} E d u_{i}+\beta_{4} E x p+\frac{\beta_{5} E x p^{2}}{100} \\
& +\beta_{6} \text { Immigrant }+\beta_{7} \text { Part }- \text { time } \\
& +\sum_{s=8}^{24} \beta_{s} \text { Occup }_{s-7}+\sum_{m=25}^{34} \beta_{m} \text { Sec }_{m-24}+u
\end{aligned}
$$

where $\ln W a g e$ is the natural logarithm of gross hourly wages, calculated as a simple division of monthly gross wage by monthly paid hours. ${ }^{45}$ Female is the gender dummy variable that takes a value one if the worker is female and $E d u_{i}$ stands for two educational attainment dummies corresponding to secondary education and high education levels (leaving out the low education as a reference category). ${ }^{46} \operatorname{Exp}$ represents labor market experience. ${ }^{47}$ Immigrant is an indicator function that takes a value of one if the country of birth is not Spain. Part-time is a dummy variable which takes a value of one if the individual is employed part-time. Ocсup $p_{s}$ and $S_{e c}$ are the eighteen occupation group dummies and twelve sector (economic activity) dummies based on the International Standard Classification of Occupations (ISCO-88) and the Statistical Classification of Economic Activities (NACE).

The Ordinary Least Squares (OLS) estimation results are shown in Table 7. The first row of the table shows the gender wage gap under different specifications. We start our analysis focusing on the observed gender gap, obtained by regressing log hourly wages on a gender dummy without any additional controls. Then we run a simple human capital wage regression that controls for the individual specific characteristics (including a constant term and only the first five control variables) and finally move to the expanded wage model that controls for the whole set of control variables. As the first

\footnotetext{
45 Wages are deflated by using the harmonized consumer price index $(\mathrm{HCPI}=2005)$ extracted from OECD Main Indicators database.

46 The education variable from ECHP and EU-SILC is harmonized by using the International Standard Classification of Education (hereafter, ISCED) categories. High educational qualifications are defined as ISCED categories 5-7, and include recognized third level education. Secondary education is defined by ISCED categories 3 and 4, and includes all second stage of secondary level education. Low education is defined as having no qualifications or only qualifications below the secondary education level, and corresponds to ISCED categories 0-2.

47 EU-SILC provides the exact number of years spent in paid work. On the other hand, ECHP lacks the information on actual labor market experience. However it provides information about the age of individuals at the highest level of education completed and at the beginning of the working life as well as the number of continuous months of unemployment before current job. Using these variables we generate a proxy for labor market experience.
} 


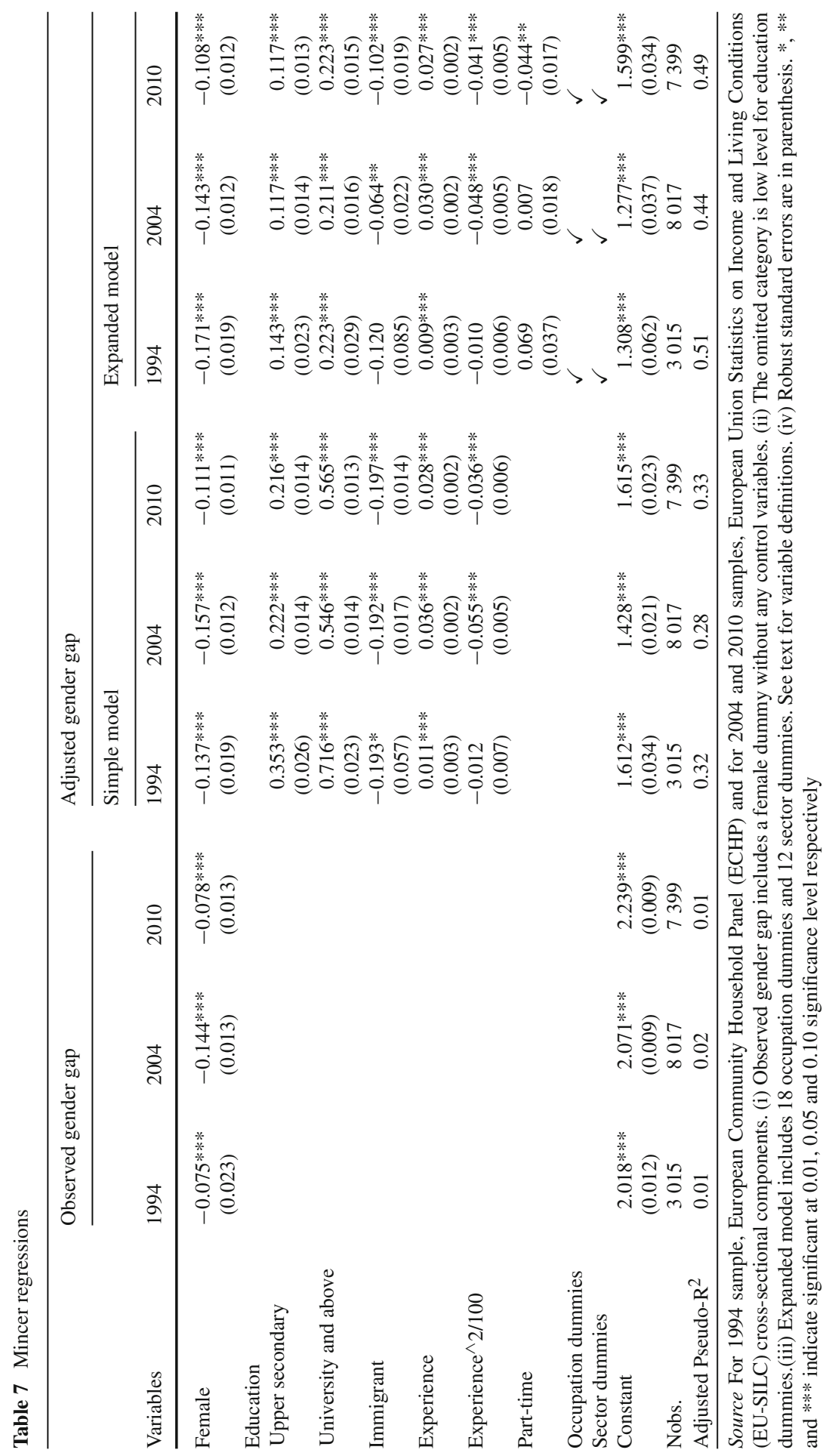


three columns of Table 7 show, the observed gender gap increased from $7.5 \%$ in 1994 to $14.4 \%$ in 2004 but then declined to $7.8 \%$ in 2010 . Once the observed characteristics of women (simple model) are controlled, the gender wage gap is substantially higher than the observed gender wage gap, which suggests that characteristics of women who work help to reduce the gross wage gap with respect to men. When we also include job characteristics (expanded model), the gender wage gap only changes only slightly. According to the estimates using the expanded model, the gender wage gap was $17.1 \%$ in 1994 and declined to $14.3 \%$ in 2004 and to $10.8 \%$ in $2010 .^{48}$

The results in Table 7 also highlight some other aspects of the wage structure in Spain. First, there is a wage penalty to be an immigrant. The penalty was $12 \%$ in 1994, declined to $6 \%$ in 2004 and increased again to $10 \%$ in 2010 . Second, there was not any penalty associated with part-time work in 1994 and 2004. A part-time work penalty of $4 \%$ emerges in 2010, which suggest that labor market is becoming less flexible and might partly reflect the effect of crisis in the labor market. Finally, skill premium has been very stable between 1994 and 2010.

Quantile regressions: In order to investigate the gender wage gaps at different points of the wage distribution, we also estimate a series of quantile regressions for 1994, 2002 and 2010. The quantile regressions technique, introduced by Koenker and Bassett (1978), seeks to extend the analysis to the whole wage distribution and provides a more complete picture of the covariate effects. The quantile regression estimation results for various specifications are reported in Table 8 . Each panel in Table 8 reports the quantile regression estimation results for various specifications for 1994, 2004 and 2010. We start again by estimating the observed gender gap and then move to the adjusted gender gap obtained from the simple and expanded models. We present coefficient estimates and standard errors of the female dummy in each specification for the fifth, tenth, twenty-fifth, fiftieth, seventy-fifth, ninetieth and ninety-fifth percentiles. For comparison, the mean OLS estimate of the gender dummy coefficient in each model is also displayed in the last column of the table. The gender dummy coefficients in the tables present the gender gap that remains unexplained at the various quantiles of the wage distribution after controlling for the covariates in each specification.

As Table 8 shows, all estimates are negative for each year and each specification, which indicates the existence of a gender gap along the entire wage distribution in Spain. The observed gender gap is highest at the bottom and at the top of the wage distribution in 1994 and follows an inverse U-shape, which suggests the existence of both sticky-floor and glass-ceiling effects. The inverse U-shape, however, starts to disappear in 2004. This is mainly due to the increase of the gender wage gap at the middle quantiles of the wage distribution. From 2004 to 2010, the observed gender gap is decreasing in each quantile. The decrease at the bottom of the wage distribution over these sixteen years is very significant; the gender gap at the 5th quantile decreased from 0.16 to 0.08 between 1994 and 2010. The gender gap at the 95th quantile decreased from 0.10 to 0.06 between 1994 and 2010. When we move to

\footnotetext{
48 Hospido (2009) uses the European Community Household Panel 1994-2001 to study work histories of young workers. She finds that there is a gender wage penalty associated to interruptions and to mobility, which might be responsible for differences in early-career wage growth between men and women.
} 


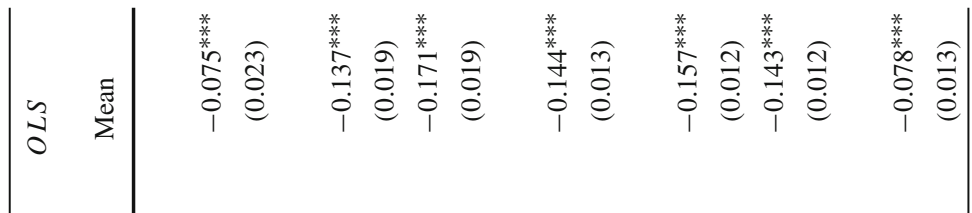

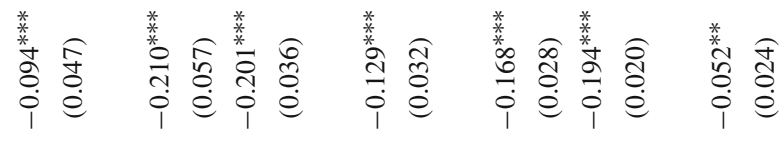

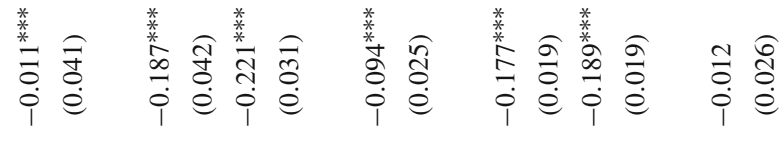

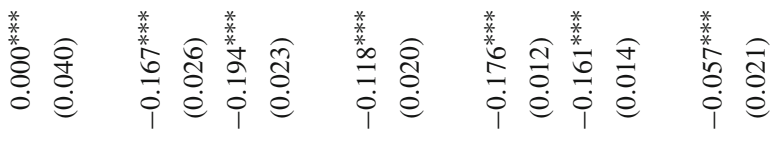

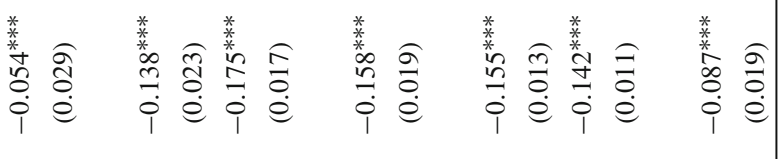

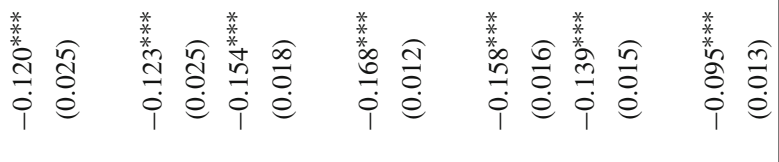

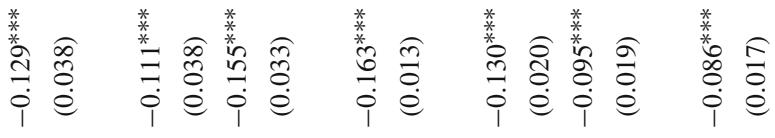

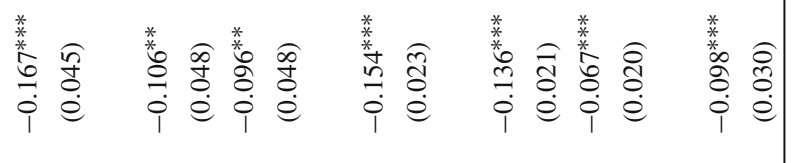

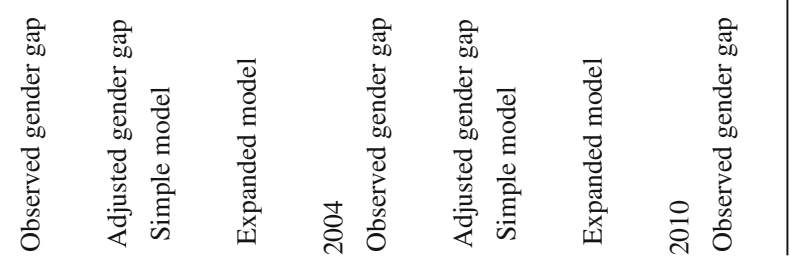




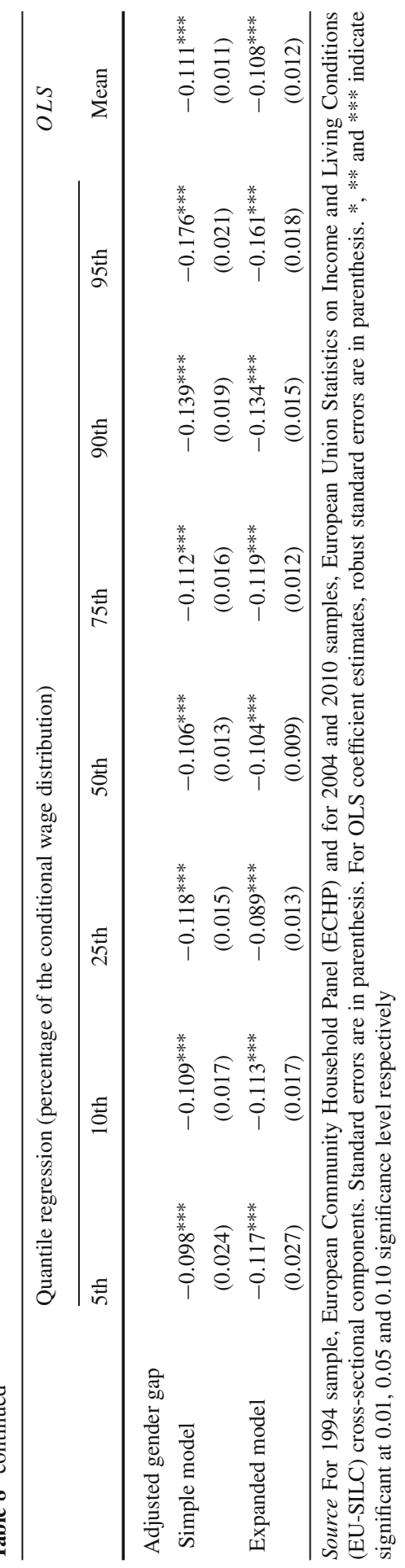


the second and third rows of each panel in Table 8 and start adding controls for relevant labor market characteristics this picture starts to change dramatically. First, the gender dummy coefficient is increasing with quantiles for each year (glass-ceiling effect). Hence, the gender wage gap that remains unexplained is higher in the upper tail of the wage distribution than at the median and the lower tail. Moreover the sticky-floor effect is also present in 2010. Second, the decline in the gender gap over time is now much less visible. Indeed, for the expanded model, the gender gap increases between 1994 and 2010 for the lowest (5th percent) quantile. ${ }^{49}$

Oaxaca decomposition: In order to explore the relative weights of the factors causing the gender wage differentials, we now display the Oaxaca decomposition results. The basic idea is to split the observed gender gap into a part that can be explained by gender differences in observed characteristics and an unexplained or residual part that cannot be accounted for by such differences. The wage differential between males and females can be written in the following way

$$
\begin{aligned}
\bar{X}^{\text {female }} \hat{\beta}^{\text {female }}-\bar{X}^{\text {male }} \hat{\beta}^{\text {male }}= & \left(\bar{X}^{\text {female }}-\bar{X}^{\text {male }}\right) \hat{\beta} \\
& +\left[\bar{X}^{\text {female }}\left(\hat{\beta}^{\text {female }}-\hat{\beta}\right)+\bar{X}^{\text {male }}\left(\hat{\beta}-\hat{\beta}^{\text {male }}\right)\right]
\end{aligned}
$$

where $\bar{X}^{\text {female }}$ and $\bar{X}^{\text {male }}$ are the average attributes of the male and female workers, $\hat{\beta}^{\text {male }}$ and $\hat{\beta}^{\text {female }}$ are the coefficient estimates from separate regressions for males and females, and $\widehat{\beta}$ is a coefficient obtained from the pooled regression of males and females. ${ }^{50}$ In this expression, the first term captures the gender gap that can be accounted for by observed differences in labor market characteristics between females and males, while the second term is the sum of female disadvantage plus the male advantage. This term, the unexplained gender wage gap, is usually interpreted as a measure of discrimination (although it can also capture potential effects of gender differences in unobserved variables).

Table 9 shows the results of the Oaxaca decomposition analysis based on the expanded model. The first row shows the observed (unadjusted) gender gap. As we have noted above, gender gap increased from 1994 to 2004 and decreased between 2004 and 2010. We find that the unexplained part of the observed gender wage gap has

\footnotetext{
49 De la Rica et al. (2008) perform a similar analysis for different levels of education attainment in Spain, using data from the European Community Household Panel. They show that for the college/tertiary education group, the gender wage gap is higher at the upper tail than at the lower tail of the wage distribution. On the other hand, they find that for the lower education group, the gap is much higher at the bottom than at the top of the distribution, which they interpret as statistical discrimination by employers, due to low participation rates of women in the lower education group. De la Rica et al. (2010) analyze the gender wage gap in the performance-pay component of total hourly wages and its contribution to the overall gender gap in Spain. After controlling for observable differences in individual and job characteristics as well as for non-random selection, the adjusted gender gap in performance pay reaches 26 log points, displaying a glass-ceiling pattern.

50 Note that if the model includes a constant, this would lead to a zero difference between the average of the males' and females' characteristics with respect to this term. Otherwise, there would be a non-zero constant difference, unless the constant terms are equal for the males and females regressions. This is why there is a contribution of the constant term to the unexplained part whereas the contribution of the constant to the explained part is zero.
} 
Table 9 Oaxaca decomposition of observed gender gap

\begin{tabular}{|c|c|c|c|}
\hline & 1994 & 2004 & 2010 \\
\hline Observed gender gap & $\begin{array}{c}-0.075^{* * *} \\
(0.023)\end{array}$ & $\begin{array}{c}-0.144^{* * *} \\
(0.013)\end{array}$ & $\begin{array}{c}-0.078^{* * *} \\
(0.013)\end{array}$ \\
\hline Explained & $\begin{array}{l}0.097^{* * *} \\
(0.019)\end{array}$ & $\begin{array}{r}-0.001 \\
(0.009)\end{array}$ & $\begin{array}{l}0.033^{* * *} \\
(0.010)\end{array}$ \\
\hline Education & $\begin{array}{l}0.028^{* * *} \\
(0.005)\end{array}$ & $\begin{array}{l}0.027^{* * *} \\
(0.003)\end{array}$ & $\begin{array}{l}0.029^{* * *} \\
(0.003)\end{array}$ \\
\hline Immigrant & $\begin{array}{r}-0.002 \\
(0.002)\end{array}$ & $\begin{array}{c}0.000 \\
(0.000)\end{array}$ & $\begin{array}{l}0.002^{* *} \\
(0.001)\end{array}$ \\
\hline Experience & $\begin{array}{c}-0.019^{* * *} \\
(0.004)\end{array}$ & $\begin{array}{c}-0.048^{* * *} \\
(0.004)\end{array}$ & $\begin{array}{c}-0.037^{* * *} \\
(0.003)\end{array}$ \\
\hline Part-time & $\begin{array}{c}0.008^{*} \\
(0.005)\end{array}$ & $\begin{array}{c}0.001 \\
(0.003)\end{array}$ & $\begin{array}{c}-0.007^{* * *} \\
(0.003)\end{array}$ \\
\hline Occupation & $\begin{array}{l}0.084^{* * *} \\
(0.017)\end{array}$ & $\begin{array}{l}0.031^{* * *} \\
(0.008)\end{array}$ & $\begin{array}{l}0.038^{* * *} \\
(0.007)\end{array}$ \\
\hline Sector & $\begin{array}{c}0.003 \\
(0.015)\end{array}$ & $\begin{array}{r}-0.012^{*} \\
(0.010)\end{array}$ & $\begin{array}{c}0.009^{*} \\
(0.005)\end{array}$ \\
\hline Unexplained & $\begin{array}{c}-0.171^{* * *} \\
(0.019)\end{array}$ & $\begin{array}{c}-0.143^{* * *} \\
(0.012)\end{array}$ & $\begin{array}{c}-0.108^{* * *} \\
(0.012)\end{array}$ \\
\hline Education & $\begin{array}{c}0.010 \\
(0.030)\end{array}$ & $\begin{array}{r}-0.025 \\
(0.017)\end{array}$ & $\begin{array}{c}0.024 \\
(0.017)\end{array}$ \\
\hline Immigrant & $\begin{array}{r}-0.003 \\
(0.004)\end{array}$ & $\begin{array}{c}0.001 \\
(0.003)\end{array}$ & $\begin{array}{l}0.010^{* * *} \\
(0.003)\end{array}$ \\
\hline Experience & $\begin{array}{c}0.032 \\
(0.045)\end{array}$ & $\begin{array}{c}-0.085^{* * *} \\
(0.031)\end{array}$ & $\begin{array}{r}-0.050 \\
(0.036)\end{array}$ \\
\hline Part-time & $\begin{array}{r}-0.000 \\
(0.004)\end{array}$ & $\begin{array}{c}0.004 \\
(0.003)\end{array}$ & $\begin{array}{c}0.005^{*} \\
(0.003)\end{array}$ \\
\hline Occupation & $\begin{array}{c}0.095 \\
(0.102)\end{array}$ & $\begin{array}{c}-0.135^{* *} \\
(0.055)\end{array}$ & $\begin{array}{c}0.040 \\
(0.051)\end{array}$ \\
\hline Sector & $\begin{array}{c}0.061 \\
(0.086)\end{array}$ & $\begin{array}{l}0.122^{* *} \\
(0.054)\end{array}$ & $\begin{array}{c}0.047 \\
(0.042)\end{array}$ \\
\hline Constant & $\begin{array}{c}-0.367^{* *} \\
(0.149)\end{array}$ & $\begin{array}{r}-0.026 \\
(0.083)\end{array}$ & $\begin{array}{c}-0.186^{* *} \\
(0.078)\end{array}$ \\
\hline
\end{tabular}

Data Source For 1994 sample, European Community Household Panel (ECHP) and for 2004 and 2010 samples, European Union Statistics on Income and Living Conditions (EU-SILC) cross-sectional components. Robust standard errors are in parenthesis.*, ** and *** indicate significant at 0.01, 0.05 and 0.10 significance level respectively

also decreased over these years. What is striking, however, is that the unexplained part of the gender wage gap is much larger than the observed gender wage gap in each year. Furthermore, the explained part of the gender wage gap is positive in 1994 and 2010 (insignificant in 2004), i.e. in spite of the advantageous condition of women in terms of their labor market characteristics, the relative wage disadvantage of women persists 
mainly due to differences in the rewards to labor market characteristics. Although this could be due to unobserved characteristics or factors that we fail to control for, it can also reflect labor market discrimination against women. We next extend this analysis to the entire wage distribution in Spain. 51

Machado and Mata decomposition: Following the traditional Oaxaca (1973) decomposition of effects on mean wages, Machado and Mata (2005) propose a decomposition method combining quantile regressions and the bootstrapping approach. Like the Oaxaca decomposition technique, the Machado-Mata decomposition calculates the relative importance of observed characteristics and the coefficients on these characteristics at different points of the wage distribution.

The difference between male and female wage distribution at the $\theta$ th quantile is written as

$$
\begin{aligned}
& X^{\text {female }} \widehat{\beta}^{\text {female }}(\theta)-X^{\text {male }} \widehat{\beta}^{\text {male }}(\theta) \\
& \quad=\left(X^{\text {female }}-X^{\text {male }}\right) \widehat{\beta}^{\text {male }}(\theta)+X^{\text {female }}\left[\widehat{\beta}^{\text {female }}(\theta)-\widehat{\beta}^{\text {male }}(\theta)\right],
\end{aligned}
$$

where $\hat{\beta}(\theta)$ is the $\theta$ th quantile regression coefficient. We again focus on the extended model. First, we construct the counterfactual densities using the expanded model. The counterfactual density is constructed assuming that women keep their own labor market characteristics but they are rewarded for these characteristics as males are, the ( $\left.X^{\text {female }} \hat{\beta}^{\text {male }}(\theta)\right)$ term. This allows us to calculate two components of the difference between the $\theta^{\text {th }}$ quantile of the female wage distribution and the $\theta^{\text {th }}$ quantile of the male wage distribution: (i) the contribution of the differences in labor market characteristics of female and male workers (the first term on the right hand side of the above expression) and (ii) the contribution of the coefficients/rewards (the second term on the right hand side of the above expression).

The results are presented in Fig. $16 .{ }^{52}$ As we mentioned above, for all years we observed gender wage gaps at each quantile of the wage distribution (Fig. 16a). Furthermore, gender differences in rewards are responsible for the observed gender wage gap, i.e. while the effects of labor market characteristics are usually positive, the effect of coefficients are negative over the entire wage distribution, and, quantitatively, the

\footnotetext{
51 Using Encuesta de Estructura Salarial (EES) (Gardeazábal and Ugidos 2005) also report the unexplained component to be 75 percent of the average gender wage gap in 1995. They also control for regional dummies and the type of labor agreement that settles wages in the firm as controls. Amuedo-Dorantes and De la Rica (2006), using the same data set, report that the raw gender gap decreased from 0.24 to 0.14 between 1995 and 2002 .

52 The decomposition of differences in wage distributions is applied using the STATA command rqdeco (See Melly (2007)). Melly (2006) shows that this procedure is numerically identical to the Machado and Mata (2005) decomposition method when the number of simulations used in Machado and Mata procedure goes to infinity. In the decomposition procedure of our study, rather than taking random draws from $(0,1)$ and estimating quantile regression coefficients, the decomposition is performed for the 99 percentile differences in wages between men and women. 100 quantile regressions are estimated in the first step and the standard errors for the counterfactual densities are obtained by repeating the procedure 100 times. Given the size of the dataset and the computational limitations, it was not feasible to perform the decomposition on the whole sample. Therefore, in this part of the analysis a random sample of the data consisting of $20 \%$ of the whole data is used.
} 

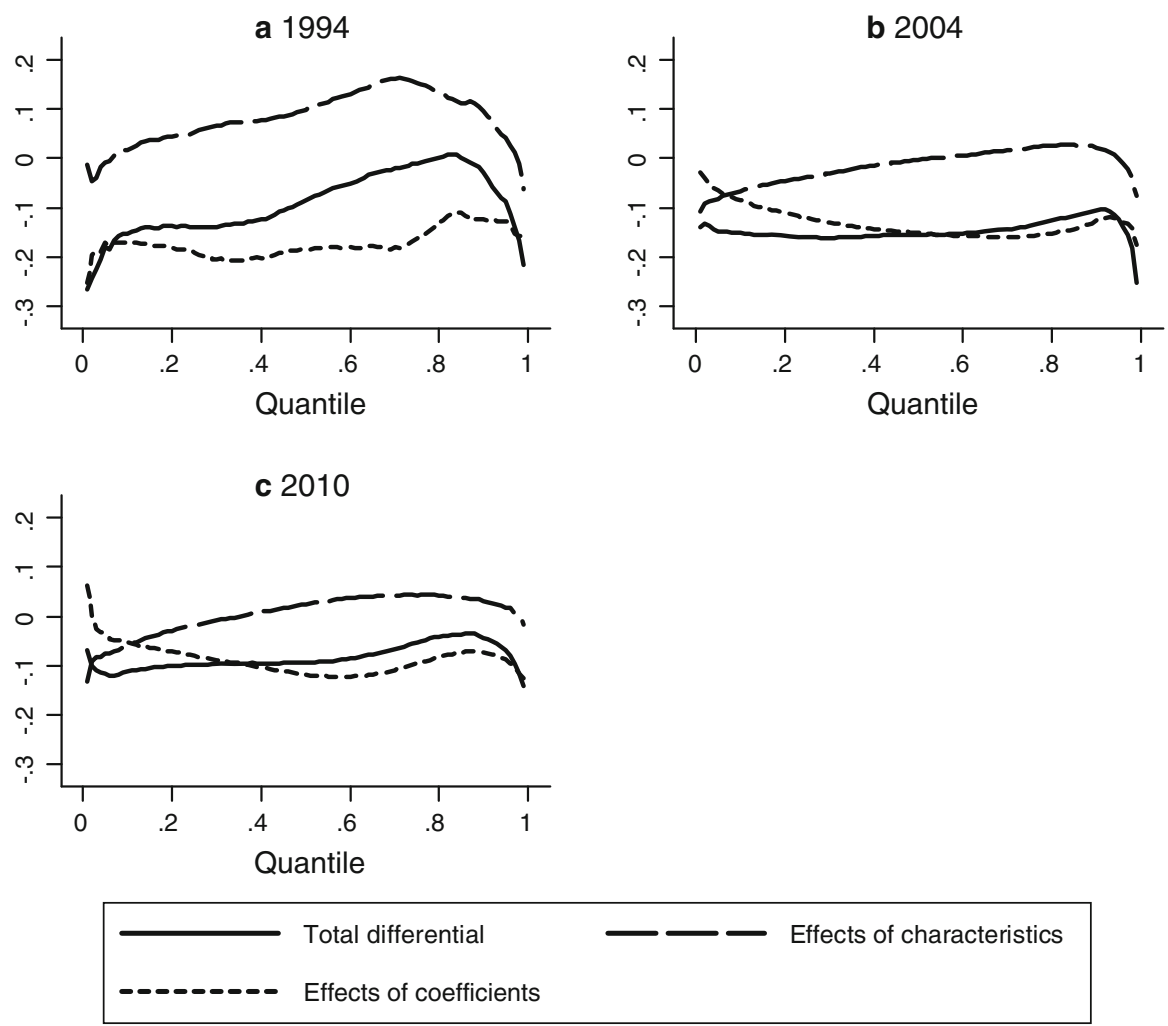

Source: For 1994, European Community Household Panel (ECHP) and for 2004 and 2010, European Union Statistics on Income and Living Conditions (EU-SILC) cross-sectional components

Fig. 16 Decomposition of observed gender gap

second effect is more important than the first one. In 1994, the gender wage gap is highest both at the bottom (glass-ceiling) and at the top of the wage distribution (sticky-floor). While differences in returns are responsible for gaps at the bottom, the observed gender gap at the top is mainly due to the increasing differences in characteristics. This pattern is also seen in 2004 and in 2010 (Fig. 16b,c), although the sticky-floor pattern is relatively less distinctive in both years while the glass-ceiling effect remains significant.

Selection bias correction: Finally, in Table 10 we present estimates of the gender wage gap after we control for self-selection of women into the labor market using the standard Heckman correction. We find that for the extended model the wage gender gap almost doubles in 2004 and 2010 when we control for selection: it is $18.0 \%$ in 1994, $29.1 \%$ in 2004 and $21.4 \%$ in 2010 . These results indicate that there is strong positive self-selection into the labor market and more productive women are the ones who choose to work. This is consistent with Olivetti and Petrongolo (2008) who find that there exists a negative correlation between the gender wage gap and the gender employment gap across countries. Hence in countries where there is a large gender gap in employment, such as Spain, the observed gender gap is low since women who 
Table 10 Estimated gender wage gaps, the importance of selection

\begin{tabular}{lccc}
\hline & 1994 & 2004 & 2010 \\
\hline Uncorrected estimates & & & \\
Observed (unadjusted) & $-0.075 * * *$ & $-0.144 * * *$ & $-0.078^{* * *}$ \\
& $(0.023)$ & $(0.013)$ & $(0.013)$ \\
Adjusted & $-0.171 * * *$ & $-0.143 * * *$ & $-0.108 * * *$ \\
& $(0.019)$ & $(0.012)$ & $(0.012)$ \\
Corrected estimates & & & $-0.181 * * *$ \\
Observed (unadjusted) & $-0.084 * * *$ & $-0.291 * * *$ & $(0.019)$ \\
& $(0.057)$ & $(0.043)$ & $-0.214 * * *$ \\
Adjusted & $-0.180 * * *$ & $-0.291 * * *$ & $(0.019)$ \\
\hline
\end{tabular}

Data Source For 1994 sample, European Community Household Panel (ECHP) and for 2004 and 2010 samples, European Union Statistics on Income and Living Conditions (EU-SILC) cross-sectional components. (i) Observed gender gap is computed as the difference of the male and female average log hourly wages obtained by estimating female dummy coefficient from regressing hourly wages only on a female dummy and a constant term. (ii) Adjusted gender gap is computed as the difference of the male and female average log hourly wages obtained by estimating female dummy coefficient from the expanded model, i.e. by regressing hourly wages on a female dummy, education (two dummies), potential experience, and potential experience squared, immigrant dummy, part-time, occupation (18 dummies), sector (12 dummies), and a constant term. (iii) Corrected estimates based on the Heckman's two step consistent estimator. (iv) The participation equation includes education (two dummies), age, immigrant dummy, marital status, number of children, non-labor family income and a constant term. (v) Robust standard errors are in parenthesis. *, $* *$ and $* * *$ indicate significant at $0.01,0.05$ and 0.10 significance level respectively

work tend to have better labor markets skills than those who choose not to work. The selection-corrected measured of the gender wage gap declined between 2004 and 2010, but the gap is still substantial and larger than its 1994 value. ${ }^{53}$

\section{Conclusions}

In this paper we document recent trends in gender equality in employment and wages in Spain. First our results show that the last few decades have witnessed a huge decline in the gender gap in employment as women, in particular married women, have entered the labor force. Our analysis shows that this is not just a result of compositional changes in the population. There remain, however, significant differences between the employment patterns of males and females, as females are less likely to work, and if they do work they are more likely to be employed part time and with temporary contracts. These differences are more pronounced for women with children younger than 3. Female employment is also concentrated in lower paid jobs (such as clerical support and service and sales). Second, there have been several important policy changes that try to help families reconcile family responsibilities with market work.

\footnotetext{
53 One reason for such improvements may be related to the way the recession took place in Spain, eroding wages in sectors were the fraction of men is much higher than the fraction of women, such as construction.
} 
The existing literature suggests that households do react to incentives generated by different policies and policy changes are at least partly responsible for changes in female labor supply. Another significant factor has been the large inflow of immigrants that provided relatively cheap household services for more educated women and allowed them to enter the labor market. Policy challenges, however, remain. The availability and cost of child care is, as in many other countries, an important constraint on female labor supply. Parental leave policies seem to be quite ineffective. Finally, there are several aspects of the Spanish labor market, e.g. the way the working day is divided, that place limits flexibility that is key for combining market and household work. Third, female employment growth in Spain has occurred together with a dramatic decline in fertility, and how labor market and fertility decisions interact remains an open question for future research. ${ }^{54}$ Fourth, and finally, the adjusted gender gap (after controlling for worker and job characteristics as well as for selection) was about $20 \%$ in 2010 and not much different from its 1994 level. Furthermore, the gender gap in wages is driven mainly by differences in returns to individual characteristics. While women are more qualified than men in observable labor market characteristics, they end up earning less. Our results also suggest that there are both sticky-floor and glass-ceiling effects on female wages.

Open Access This article is distributed under the terms of the Creative Commons Attribution License which permits any use, distribution, and reproduction in any medium, provided the original author(s) and the source are credited.

\section{References}

Adeserá A (2006) An economic analysis of the gap between desired and actual fertility: the case of Spain. Rev Econ Househ 4(1):75-95

Adeserá A (2011) Where are the babies? Labor market conditions and fertility in Europe. Eur J Popul 27(1):1-32

Ahn N, Mira P (2001) Job bust, baby bust? Evidence from Spanish data. J Popul Econ 14(3):505-521

Alba A, Alvarez G, Carrasco R (2009) On the estimation of the effect of labour participation on fertility. Span Econ Rev 11(1):1-22

Amuedo-Dorantes C, De la Rica S (2006) The role of segregation and pay structure on the gender wage gap: evidence from matched employer-employee data for Spain. BE J Econ Anal Policy Contrib 5(1): $1-34$

Amuedo-Dorantes C, De la Rica S (2010) Timing of work and work-family conflicts in Spain: who has a split work schedule and why? IZA Discussion Paper 4542

Arellano M, Bover O (1995) Female labour force participation in the 1980s: the case of Spain. Investigaciones Económicas 19(2):171-194

Attanasio O, Low H, Sánchez-Marcos V (2008) Explaining changes in female labour supply in a life-cycle model. Am Econ Rev 98(4):1517-1542

Azmat G, González L (2010) Targeting fertility and female participation through the income tax. Labour Econ 17(3):487-502

Azmat G, Guell M, Manning A (2006) Gender gaps in unemployment rates in OECD countries. J Labor Econ 24(1):1-38

Baizán P (2009) Regional child care availability and fertility decisions in Spain. Demogr Res 21(27):803842

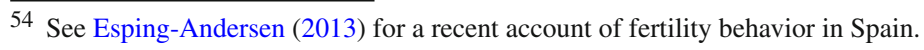


Bagues M, Esteve-Volart B (2010) Can gender parity break the glass ceiling? Evidence from a repeated randomized experiment. Rev Econ Stud 77(4):1301-1328

Bentolila S, Cahuc P, Dolado JJ, Le Barbanchon T (2010) Two-tier labor markets in the Great Recession: France vs. Mimeo, Spain

Berge TJ, Jorda O (2013) A chronology of turning points in economic activity: Spain, 1950-2011. SERIEs 4(1):1-34

Brindusa A, De la Rica S, Lacuesta A (2013) Employment Polarization in Spain along the cycle 1997-2012. IZA Discussion Paper No. 7816

Blau FD, Ferber MA, Winkler AE (2002) The economics of women, men and work, 4th edn. Prentice Hall, New Jersey

Bick A (2012) The quantitative role of child care for female labor force participation and fertility. Mimeo

Blázquez M, Ramos NE (2009) Part-time employment: a comparative analysis of Spain and the Netherlands. Eur J Law Econ 28(3):223-256

Brassiolo PA (2012) Essays on the economics of family formation, Dissolution and Bargaining. PhD Thesis, Universitat Pompeu Fabra

Carro J, Mira P (2006) A dynamic model of contraceptive choice of Spanish couples. J Appl Econ 21(7):955980

Caucutt E, Guner N, Knowles J (2002) Why do women wait? Matching, wage inequality and the incentives for fertility delay. Rev Econ Dyn 5(4):815-855

Consumer (2005) Siguen faltando plazas en las guarderías públicas. Revista Consumer Eroski 91

Costain J, Jimeno JF, Thomas C (2010) Employment fluctuations in a dual labor market. Banco de España Working Papers 1013

Crespo L, Mira P (2013) Caregiving to elderly parents and employment status of European mature women. Revi Econ Stat (forthcoming)

Cuadrado P, Lacuesta A, Martínez JM, Pérez E (2007) El futuro de la tasa de actividad española: un enfoque generacional. Banco de España Working Papers 0732

De la Rica S, Ferrero D (2003) The effect of fertility on labour force participation: the Spanish evidence. Span Econ Rev 5(2):153-172

De la Rica S, Iza A (2005) Career planning in Spain: do fixed-term contracts delay marriage and parenthood? Rev Econ Househ 3(1):49-73

De la Rica S, Dolado JJ, Llorens V (2008) Ceilings or floors? Gender wage gaps by education in Spain. J Popul Econ 21(3):751-776

De la Rica S, Dolado JJ, Vegas R (2010) Performance pay and the gender wage gap: evidence from Spain. Ann Econ Stat (forthcoming)

Da Rocha JM, Fuster L (2006) Why are fertility rates and female employment ratios positively correlated across OECD countries? Int Econ Rev 47(4):1187-1222

Dolado JJ, Felgueroso F, Jimeno JF (2001) Female employment and occupational changes in the 1990s: how is the EU performing relative to the US? Eur Econ Rev 45(4-6):875-889

Dolado JJ, Felgueroso F, Jimeno JF (2004) Where do women work: analyzing patterns in occupational segregation by gender? Annales d'Economie et de Statistique 71-72

Dolado JJ, Felgueroso F, Almunia M (2012) Are men and women-economists evenly distributed across research fields? Some new empirical evidence. SERIEs 3(3):367-393

Erosa A, Fuster L, Restuccia D (2010) A general equilibrium analysis of parental leave policies. Rev Econ Dyn 13(4):42-58

Esping-Andersen G (2013) El déficit de natalidad en Europa. La singularidad del caso español. Obra Social "la Caixa"

Farré L, González L, Ortega F (2011) Immigration, family responsibilities and the labor supply of skilled native women. BE J Econ Anal Policy Contrib 11(1)

Fernández-Kranz D, Rodríguez-Planas N (2013) Can parents' right to work part-time hurt childbearing-aged women? A Natural Experiment with Administrative Data, IZA Discussion Papers 7509

García-Morán E, Koehn Z (2012) With strings attached: grandparent-provided childcare, fertility, and female labor market outcomes. MPRA Paper No. 38393

García-Pérez JI, Jiménez S, Sánchez-Martín A (2010) Retirement incentives, individual heterogeneity and labour transitions of employed and unemployed workers. FEDEA Working Papers 2010-27

Gardeazábal J, Ugidos A (2005) Gender wage discrimination at quantiles. J Popul Econ 18(1):165-179

Gray JS (1998) Divorce-Law changes, household bargaining, and married women's labor supply. Am Econ Rev 88(3):628-642 
Goldin C, Katz LF (2002) The power of the pill: oral contraceptives and women's career and marriage decisions. J Polit Econ 110(4):730-770

González L (2013) The effects of a universal child benefit on conceptions, abortions, and early maternal labor supply. Am Econ J Econ Policy 5(3):160-188

Guner N, Kaygusuz R, Ventura G (2013) Childcare subsidies and household labor supply. CEPR Discussion Paper No. DP9775

Gutiérrez-Domenech M (2005) Employment after motherhood: a European comparison. Labour Econ 12(1):99-123

Gutiérrez-Domenech M (2008) The impact of the labour market on the timing of marriage and births in Spain. J Popul Econ 21(1):83-110

Hospido L (2009) Gender differences in wage growth and job mobility of young workers in Spain. Investigaciones Económicas 33(1):5-37

Johnson WR, Skinner J (1986) Labor supply and marital separation. Am Econ Rev 76(3):455-469

Kapan T (2008) Property division laws: the effects on labor supply and household bargaining. PhD Thesis, Columbia University

Kaygusuz R (2010) Taxes and female labour supply. Rev Econ Dyn 13(4):725-741

Koenker R, Bassett G (1978) Regression quantiles. Econometrica 46(1):33-50

Lapuerta I, Baizán P, González MJ (2010) Individual and institutional constraints: an analysis of parental leave use and duration in Spain. Popul Res Policy Rev 30(2):185-210

Machado J, Mata J (2005) Counterfactual decomposition of changes in wage distribution using quantile regression. J Appl Econ 20(4):445-465

Melly B (2006) Estimation of counterfactual distributions using quantile regression. mimeo

Melly B (2007) Rqdeco: a Stata module to decompose differences in distribution. mimeo

Miller A (2011) The effects of motherhood timing on career path. J Popul Econ 24(3):1071-1100

Nollenberger N, Rodriguez-Planas N (2011) Child care, maternal employment and persistence: a natural experiment from Spain. IZA Discussion Papers 5888

Oaxaca R (1973) Male-female wage differentials in urban labor markets. Int Econ Rev 14(3):693-709

OECD (2007) Babies and bosses-reconciling work and family life: a synthesis of findings for OECD Countries. OECD Publishing, Paris

OECD (2008) The price of prejudice: labour market discrimination on the grounds of gender and ethnicity. In: OECD employment outlook 2008, Chap. 3. OECD Publishing, Paris

OECD (2010a) Gender brief. OECD social policy division. OECD Publishing, Paris

OECD (2010b) Education at a glance. OECD Publishing, Paris

OECD (2010c) Employment outlook 2010. OECD Publishing, Paris

Olivetti C (2006) Changes in women's hours of market work: the effect of changing returns to experience. Rev Econ Dyn 9(4):557-587

Olivetti C, Petrongolo B (2008) Unequal pay or unequal employment? A cross-country analysis of gender gaps. J Labor Econ 26(4):621-654

Parkman AM (1992) Unilateral divorce and the labor-force participation rate of married women, revisited. Am Econ Rev 82(3):670-678

Ruhm CJ (1998) The economic consequences of parental leave mandates: lessons from Europe. Q J Econ 112(1):285-317

Sahin A, Song J, Hobijn B (2010) The unemployment gender gap during the 2007 recession. Federal Reserve Bank of New York: Current Issues in Economics and Finance 16(2)

Sánchez-Mangas R, Sánchez-Marcos V (2008) Balancing family and work: the effect of cash benefits for working mothers. Labour Econ 15(6):1127-1142

Sánchez-Marcos V (2013) Female labor market outcomes and parental leave policies. Mimeo

Sander W (1985) Women, work and divorce. Am Econ Rev 75(3):518-523

Sen B (2000) How important is anticipation of divorce in married women's labor supply decisions: an inter-cohort comparison using NLS data. Econ Lett 67(2):209-216

Stevenson (2008) Divorce law and women's labor supply. NBER Working Paper 14346

Tobío C (2003) Políticas públicas y estrategias privadas: la conciliación familia-empleo en España. Servicio de Estudios de BBVA, Cambridge

Waldfogel J (1998) The family gap for young women in the United States and Britain: can maternity leave make a difference? J Labor Econ 16(3):505-545

Waldfogel J, Higuchi Y, Abe M (1999) Family leave policies and women's retention after childbirth: evidence from the United States, Britain, and Japan. J Popul Econ 12(4):523-554 